\title{
The potential role of hydrogen in energy systems with and without climate policy
}

\author{
Bas van Ruijven ${ }^{\mathrm{a}, *}$, Detlef P. van Vuuren ${ }^{\mathrm{b}}$, Bert de Vries ${ }^{\mathrm{a}, \mathrm{b}}$ \\ ${ }^{a}$ Copernicus Institute for Sustainable Development and Innovation, Department of Science, Technology and Society, Utrecht University, \\ Heidelberglaan 2, 3584 CS Utrecht, The Netherlands \\ ${ }^{\mathrm{b}}$ MNP-Netherlands Environment Assessment Agency, P.O. Box 1, 3720 BA Bilthoven, The Netherlands
}

Received 1 November 2005; accepted 13 March 2006

\begin{abstract}
Introduction of hydrogen in global energy system can lead to lower $\mathrm{CO}_{2}$ emissions (high end-use efficiency; low-carbon production of hydrogen) but might also increase $\mathrm{CO}_{2}$ emissions (producing hydrogen from coal). We used the long-term energy model TIMER 2.0, to study the use and production of hydrogen and its influence on global $\mathrm{CO}_{2}$ emissions. This is done using a set of scenarios with assumptions on technology development, infrastructural barriers and climate policy $(\mathrm{CP})$. We found that even under optimistic assumptions hydrogen plays a minor role in the global energy system until the mid-21st century due to the system inertia — but could become a dominant secondary energy carrier in the second half of the century. Hydrogen is mainly produced from coal and natural gas. Hence, hydrogen-rich scenarios without climate policy increase $\mathrm{CO}_{2}$ emissions up to $15 \%$ by 2100 compared to the baseline. However, if climate policy is assumed, $\mathrm{CO}_{2}$ from fossil feedstock-based hydrogen production is captured and sequestrated, which indicates that an energy system that includes hydrogen is much more flexible in responding to climate policy.
\end{abstract}

(C) 2006 International Association for Hydrogen Energy. Published by Elsevier Ltd. All rights reserved.

Keywords: Hydrogen economy; Climate policy; Long-term scenarios

\section{Introduction}

For at least several decades, the idea of hydrogen-based energy systems has attracted the attention of engineers and environmental scientists. Interest first surged in the early 1970s in response to the first oil crisis and the growing concerns about environmental issues [1-3]. The perceived advantages at that time were its nearly zero emissions (improving air quality) and the possibility of local production on the basis of a variety of fuels (decreasing dependence on imported oil) [4,5]. Interest subsided after the oil price decline in the mid-1980s but resurged in the early 2000s, now also due to its potential role in reducing greenhouse gas emissions (see for instance, initiatives from both public and private parties: [6-10]).

\footnotetext{
* Corresponding author. Tel.: +31302537686; fax: +31302537601. E-mail addresses: b.j.vanruijven@chem.uu.nl (B. van Ruijven), detlef.van.vuuren@mnp.nl (D.P. van Vuuren), bert.de.vries@mnp.nl (B. de Vries).
}

While the contribution of hydrogen in improving urban air quality and dependence on imported oil is obvious, its role in reducing climate change is less straightforward. On the one hand, the high end-use efficiency in fuel cells and the possibility to produce hydrogen from non-fossil sources or clean fossil fuels (fossil fuel combustion in combination with carbon-captureand-storage, CCS)—could reduce greenhouse gas emissions from the energy system [11-13]. On the other hand, hydrogen can also be produced from relatively cheap coal without CCS technology, which leads across the whole chain to a considerably higher carbon/energy ratio than today's energy technologies [14]. In addition, the question remains whether hydrogen-based technologies will ever be cheap enough to be an effective competitor to fossil-based and non-fossil-based technologies. These contradictory arguments contribute to the uncertainty in the contribution of hydrogen to the mitigation of greenhouse gas emission.

Model-based scenario studies have been designed to assess the role of hydrogen in future energy systems and the 
Table 1

Comparison of several hydrogen studies that use long-term global energy models

\begin{tabular}{|c|c|c|c|}
\hline & {$[13]$} & {$[12]$} & [14] \\
\hline Model & MESSAGE-MACRO & GET 1.0 & MiniCAM \\
\hline Scenario & IPCC/SRES B1-H 2 & IIASA/WEC ${ }^{\mathrm{a}}$ & IPCC/SRES B2 \\
\hline Climate target & & $400 \mathrm{ppmv}$ & $550 \mathrm{ppmv}$ \\
\hline Time & $\begin{array}{l}\text { Initiated } 2000 \\
10 \% \text { market } 2030\end{array}$ & Initiated between 2030 and 2050 & $\begin{array}{l}\text { Initiated } 2010 \\
30 \% \text { market } 2060\end{array}$ \\
\hline Production & $\begin{array}{l}\text { Small-scale SMR and off-peak electrolysis } \\
\text { Large-scale SMR with } \mathrm{CO}_{2} \text {-seq. } \\
\text { Biomass and solar thermal }\end{array}$ & $\begin{array}{l}\text { Small-scale SMR } \\
\text { Large-scale SMR and Coal with } \mathrm{CO}_{2} \text {-seq. } \\
\text { Solar }\end{array}$ & $\begin{array}{l}\mathrm{Coal} / \text { gas/biomass } \\
\mathrm{CO}_{2} \text {-seq. }\end{array}$ \\
\hline Applied in sectors & $\begin{array}{l}\text { Transport residential/service } \\
\text { industry }\end{array}$ & Transport & Transport \\
\hline End-use technology & $\begin{array}{l}\text { Micropower (also from vehicles) } \\
\text { CHP from FC plants }\end{array}$ & Fuel cells & Fuel cells and direct combustion \\
\hline Infrastructure & & Pipeline & Short pipelines, trucks, trunk lines \\
\hline
\end{tabular}

aThis is an "ecologically driven" scenario which assumes that technological development leads to efficiency improvements, so that per capita energy demand in developed countries is reduced.

potential consequences for future carbon emissions and climate policy $(\mathrm{CP})$. For this purpose, global energy models have been extended to also cover hydrogen-based technologies. These include, for instance, the MESSAGE [13], MiniCam [14] and GET [12] models. Such scenario studies, however, have not led to a single, consistent view on potential hydrogen-based energy systems. GET and MESSAGE model runs indicate a very important role of hydrogen in reducing greenhouse gas emissions $[12,13]$. Other scenarios indicate a possible increase in such emissions as a result of increasing coal uses [14]. These model results confirm the technical analysis indicating the existence of quite diverse technological pathways. Apparently, the future role of hydrogen depends on specific model assumptions-or even model structure - and the type of scenario considered (e.g. baseline or mitigation).

To explore the relationship between assumptions and outcomes for hydrogen-based energy systems in global energy models in more detail, we have performed a series of model experiments in the TIMER 2.0 model. In these experiments, we specifically look into the question which uncertainties influence the potential role of hydrogen in future energy systems and to what extent, and how the potential role of hydrogen is related to $\mathrm{CP}$.

This article describes the results of this analysis. We first summarise the results of a literature survey on assumptions for production technologies, infrastructure development and different end-use functions and related technologies. Values found in literature have been translated into pessimistic, intermediate and optimistic scenarios for hydrogen technology development. These three sets of assumptions are used as input for model experiments and scenario construction with the TIMER 2.0 model, using the TIMER B2 baseline scenario as reference (see Section 3.2). Model runs are presented for six different cases: the baseline and a climate mitigation scenario, each in combination with the three hydrogen variants mentioned above. This set allows us to explore most of the potential $\mathrm{H}_{2}$-scenarios which seem to matter on the basis of present-day insights.

\section{The future of hydrogen: what does scientific literature} say?

\subsection{Ranges of assumptions in literature as basis for scenarios}

There is a vast literature on the future possibilities of hydrogen energy. Some use full-fledged energy models, others are based on partial analyses or expert views. Focus, method and results show significant differences. Several scenario studies looking specifically into the role of hydrogen project a major role for this energy carrier in future energy systems-although timing and intensity of introduction differ significantly (see Table 1 for a subset of these scenarios). But other scenario studies, the short-term energy projections of the IEA among them, hardly pay attention to hydrogen [15]. As with several other aspects of future energy systems, there is a lively debate on pros and cons of hydrogen-based energy systems [4,16-19].

As a basis for our model experiments and scenario construction, we have done a careful analysis of published long-term hydrogen studies [20]. In the brief overview in this paper, we focus on a sub-set, for which the main characteristics are shown in Table 1. We discuss the assumptions and results of these studies in relation to three important issues: (1) the type of technologies used to produce hydrogen; (2) the type of technologies and applications in end-use; and (3) the technical and economic aspects of infrastructure developments.

\subsection{Production}

Currently, hydrogen is widely used in oil refineries, produced by steam methane reforming (SMR) and of coal and oil residues gasification. However, most carbon neutral hydrogen production technologies for energy purposes (so, large-scale and low-cost) are currently still in the laboratory phase, or at best in the demonstration phase. In literature, some studies include only those in the demonstration phase $[13,21]$, while others also include anticipated future technologies such as biophotocatalytics and photolysis [7]. While 
Table 2

Ranges of hydrogen production technology characteristics from literature

\begin{tabular}{|c|c|c|c|}
\hline Technology & Current capital cost $\left(\$ / \mathrm{kW}-\mathrm{H}_{2}\right)$ & Efficiency (\%) & Source \\
\hline Coal gasification $(\mathrm{CG})$ & $500-900$ & $60-65$ & {$[21,47,48]$} \\
\hline Partial oxidation of oil (PO) & $400-600$ & $50-60$ & [49] \\
\hline Steam methane reforming (SMR) & $100-350$ & $75-85$ & {$[21,23,50]$} \\
\hline Biomass gasification (BG) & $800-1400$ & $50-70$ & {$[21,47,48,50,51]$} \\
\hline Electrolysis (E) & $350-2000$ & $75-85$ & {$[21,23,47]$} \\
\hline Solar thermal (ST) & $3000-10000$ & 50 & {$[52,53]$} \\
\hline Small-scale steam methane reforming (SSMR) & $2000-4000$ & $75-85$ & {$[21,23,50]$} \\
\hline
\end{tabular}

Table 3

Ranges of fuel cell characteristics from literature

\begin{tabular}{|c|c|c|c|c|}
\hline Technology & Current capital cost $(\$ / \mathrm{kWe})$ & Future capital cost & Efficiency & Source \\
\hline Proton exchange membrane (PEM) mobile & $1200-1500$ & $45-600 \$ / \mathrm{kW}$ & $30-60 \%$ & {$[21,23,54]$} \\
\hline PEM stationary & 1400 & & $60 \% \mathrm{e} / 40 \%$ th & [39] \\
\hline Solid oxide fuel cell (SOFC) stationary & 1100 & & $45 \% \mathrm{e} / 35 \%$ th & [39] \\
\hline
\end{tabular}

the latter category can be important on the long term, their assessment implies a quantification bordering on speculation.

Interestingly, there is convergence regarding the initial development of a hydrogen energy system. Natural gas plays an important role, almost all transition scenarios start with small-scale production of hydrogen from natural gas via SMR, possibly in combination with electrolysis during off-peak hours $[12,13,21]$. In the long term, literature shows three different possible configurations of the large-scale hydrogen energy system:

- large-scale production of hydrogen from fossil sources, mainly coal and natural gas $[13,14,21,22]$;

- a situation with climate constraints, when a fossil-based hydrogen system can be combined with CCS [14]; and

- renewable hydrogen production, based on biomass gasification, direct solar thermal hydrogen production and electrolysis from solar or wind electricity [13].

These configurations do not necessarily exclude each other, most studies found a succession of hydrogen production technologies, mainly first fossil based and second towards a CCS or a renewable-based system.

The costs of producing hydrogen consist largely of feedstock and investment costs. Ranges for the specific investment cost and efficiency estimates for hydrogen production technologies reported in literature for the next few decades are given in Table 2. Future hydrogen production costs are generally assumed to be lower than current values as a result of technology development. For small-scale SMR, costs are generally significantly higher than that of large-scale SMR but some authors expect cost declines down to the level of large-scale SMR. We developed our scenarios, which we describe later, from these literature data (see Appendix B). We only used solar thermal hydrogen production as climate neutral backstop technology and excluded nuclear thermal.

\subsection{End-use}

The primary end-use technology associated with hydrogen is the fuel cell. Since fuel cells produce both heat and power, possible applications are almost infinite, and hence, literature on future hydrogen energy applications describes a wide range of possibilities. The main advantage of fuel cells is in vehicular applications, as they double the efficiency of transport compared to current internal combustion engines (ICEs). Another advantage is that these fuel cells theoretically can also deliver electricity to the grid while the car is parked. This application of micropower influences the central power production and makes fuel cells more profitable [5,13]. Most authors therefore project the most significant break-through of hydrogen (if any) in the future transport sector (even without electricity delivery).

A smaller number of authors expect the application of hydrogen energy in other economic sectors as well. The possibility of small-scale combined heat and power production is attractive for households and offices that can install their own fuel cell $[4,13]$. Expectations for hydrogen in the industrial sector are more moderate. As many industrial applications can be served directly by electricity or other fuels, hydrogen is expected only to fulfil niche functions [13].

So far, fuel cells are produced at a small scale at high costs, but mass production is expected to bring major cost reductions $[23,24]$. The premature stage of fuel cell technology makes literature data somewhat speculative. As shown in Table 3, literature on current cost is relatively consistent, estimating fuel cell cost about $1100-1500 \$ / \mathrm{kW}$. However, estimations of future costs vary heavily, some studies project moderate cost reductions, while others foresee enormous breakthroughs with mass production.

An aspect of fuel cells that is currently under debate is the efficiency in vehicular applications. As current ICEs have a tank-to-wheel efficiency of $15-21 \%$, and a future expected maximum of $25 \%$ (ICE-Hybrids excluded), the theoretical 
Table 4

Hydrogen infrastructure costs

\begin{tabular}{llc}
\hline Technology & Cost & Source \\
\hline $\begin{array}{l}\text { Storage (3 days) } \\
\text { Liquid }\end{array}$ & $6-18 \$ / \mathrm{GJ}$ & {$[21,55]$} \\
Compressed gas & $2-4.5 \$ / \mathrm{GJ}$ & {$[21,55]$} \\
Metal hydrides & $3-7 \$ / \mathrm{GJ}$ & {$[55]$} \\
Transport & & \\
Pipeline & $0.1-0.5 \$ / \mathrm{GJ} / 100 \mathrm{~km}$ & {$[21]$} \\
Liquid truck & $0.2-1.5 \$ / \mathrm{GJ} / 100 \mathrm{~km}$ & {$[47]$} \\
Gas truck & $4.9-29.4 \$ / \mathrm{GJ} / 100 \mathrm{~km}$ & {$[47]$} \\
Metal hydrides truck & $2.6-16.4 \$ / \mathrm{GJ} / 100 \mathrm{~km}$ & {$[47]$} \\
Distribution & & {$[21]$} \\
Refuelling station & $4-6 \$ / \mathrm{GJ}$ & \\
\hline
\end{tabular}

efficiency of fuel cells in mobile applications is definitely higher than current technology. However, as fuel cells in cars will seldom work at maximum power, estimates of the effective fuel cell efficiency are lower. Some authors project the real efficiency to be 30-36\% [25], 36-41\% for an North-American driving cycle [26] and 44-49\% for an European driving cycle [10]. We used the whole range that we found in literature for the development of our scenarios (see Appendix B).

\subsection{Infrastructure}

The introduction of hydrogen in an energy system requires substantial changes in infrastructure. Although hydrogen is currently produced and transported on a small scale for industrial purposes, large investments are needed to develop a complete infrastructure for energy applications. Most publications agree that this is the main barrier for the development of a hydrogen economy, and generally, transition studies and government route maps foresee a first period of small-scale hydrogen use in niche markets, without a need for distribution networks. From these small-scale experiments and pilot projects, the application and demand for hydrogen can increase, reaching a stage in which large-scale production becomes affordable [7,8,12,21]. As shown in Table 1, the attention paid to infrastructure development varies widely between long-term studies. Some authors explicitly include several infrastructure options and their costs [12], while others only state that infrastructure is an important aspect of hydrogen energy systems [13].

The main uncertainties in the literature on hydrogen infrastructure are costs and the form in which hydrogen is transported (gas, liquid or metal-hydrates). As hydrogen is a rather voluminous gas at normal temperature and pressure, it has to be either pressurised or liquefied. Currently, hydrogen for industrial applications is transported by trucks (liquid) or pipelines (pressurised gas). Future hydrogen energy systems can be based on both these technologies, depending on the cost development and the demand densities [12,21]. In any case, the transport infrastructure costs will contribute considerably to the hydrogen price (see Table 4). Pipelines are the cheapest way of hydrogen transport, but are only affordable in case of a high hy- drogen demand density. Distribution as a liquid by truck is also relatively cheap, but then storage and liquefation add up to the price. To deal with these uncertainties, we simulated two steps in infrastructure development in our model (see Section 3.4) and varied the costs of transport and distribution in the scenarios (see Appendix B).

\section{Modelling hydrogen in TIMER 2.0}

\subsection{The TIMER 2.0 model}

We used the TIMER 2.0 model to explore the possibilities of hydrogen in future energy systems. The TIMER 2.0 model is the energy sub-model of the Integrated Model to Assess the Global Environment, IMAGE 2.2 [27] that describes the main aspects of global environmental change. TIMER is a system-dynamics energy model that simulates year-to-year investment decisions based on a combination of bottom-up engineering information and specific rules on investment behaviour, fuel substitution and technology. TIMER 2.0 [28] is a revised version of the TIMER 1.0 model [29], with main differences being extension of renewable energy modelling [30], carbon capture and storage [31] and hydrogen [32].

In the TIMER 2.0 model the demand for end-use energy is related to the economic activity in five sectors: industry, transport, residential, services and other. The demand formulation includes autonomous and price-induced changes in energy intensity. Energy supply is based on fossil fuels (coal, oil, natural gas), biomass, solar and wind power, hydropower and nuclear power. Fossil- and biofuels can be traded among 17 world regions. The production of each primary energy carrier includes the dynamics of depletion and learning by doing. To this framework of sub-models we added a hydrogen model, which is connected to all primary energy supply models, the electricity model and the energy demand model.

\subsection{The TIMER 2.0 B2 scenario}

The baseline scenario used here is the TIMER 2.0 B2 scenario. This scenario, based on the IPCC SRES B2 scenario, assumes a continuation of present-day trends, with medium values for population and economic growth. In the implementation of the scenario, for the period 2000-2030, we have used the assumptions and results of the IEA reference scenario to roughly calibrate our scenario against (thus the same population and economic growth, and roughly similar energy use and emission trends). From 2030 onwards, population follows the UN medium scenario, while economic growth rates are based on the original B2 scenario. The global population stabilises around 2100 , at 10 billion people. The global growth rate of GDP per capita starts at $2 \%$ per year and declines slowly to $1.5 \%$ after 2050 . Most currently low-income regions have relatively high GDP per capita and energy use growth rates already early in the century. The African regions form an exception-here economic growth rates above global average only occur after 2040. Primary energy use, globally, increases 
from $400 \mathrm{EJ}$ today to $1200 \mathrm{EJ}$ in 2100 . In the first half of the century, natural gas use rises rapidly. However, in the second half of the century, oil and natural gas prices are relatively high (as result of depletion of low-cost resources). As a result, trends reverse: coal starts to gain market share in the electricity and industrial sector and represents $40 \%$ of all energy consumed by the end of the century. Carbon emissions increase from $6 \mathrm{GtC} / \mathrm{yr}$ today to $18 \mathrm{GtC} / \mathrm{yr}$ around 2100 . Compared to most scenarios published today, these should be regarded as values slightly above the medium. In the default implementation of this scenario no penetration of $\mathrm{H}_{2}$ as a major energy carrier is assumed.

\subsection{The TIMER- $\mathrm{H}_{2}$ model}

The TIMER-H $\mathrm{H}_{2}$ model involves the production, demand, infrastructure and technology dynamics of hydrogen-related technologies, as described below (see Fig. 1). In brief, hydrogen production costs are determined from capital costs, fuel costs and (if relevant) $\mathrm{CO}_{2}$ sequestration costs. The costs of energy services from hydrogen for the end-user are the sum of these hydrogen production costs (also regarding end-use efficiency) and the end-use capital cost and infrastructure costs. The market share of hydrogen is determined by the relative differences of the energy service costs on the basis of hydrogen and the same costs based on other energy carriers. The demand of hydrogen equals the market share times sectoral energy demand. Subsequently, hydrogen demand is met through investments into hydrogen production capital. Finally, there is a feedback loop from technological learning, as hydrogen production capital cost decline with increasing cumulative installed capacity.

\subsubsection{Hydrogen production}

In TIMER 2.0, hydrogen can be produced from coal gasification, partial oxidation of oil, steam reforming of natural gas, gasification of biomass, electrolysis and direct solar thermal production of hydrogen. For the production of hydrogen from natural gas, the model distinguishes between both large-scale and small-scale SMR. This is in order to simulate a transition period in which there is no infrastructure and (more expensive) small-scale SMR is the only available technology for stationary applications of hydrogen energy. The capacity, investments and depreciation of hydrogen production technologies are simulated by a vintage stock model, assuming a life-time of 30 years. The investment shares of hydrogen production technologies are based on the mutual cost differences, weighted in a multinomial logit formula (see Appendix A). The costs of feedstock for hydrogen production (coal, oil, natural gas, biomass electricity and solar) and the dynamics of carbon sequestration resources and capacity are modelled elsewhere in TIMER.

For each of the technologies, technological progress is simulated by learning-by-doing curves, describing the dynamics of decreasing cost as a function of increasing cumulative production capacity $[33,34]$. The concept is applied to the capital cost of hydrogen production technologies. We assumed technological learning to be based on global cumulative production capacity, with variations in specific cost reduction based on openness between regions and relative contribution of a region to the global cumulative production capacity. Parameterisation of technological learning is derived from Barreto et al. [13], with variations in scenarios. We were not able to find literature estimates of learning parameters for solar thermal and small-scale SMR. For these technologies we used a hybridlearning method: initially the costs of solar thermal and smallscale SMR decrease with a constant rate, between $0.4 \%$ and $1.5 \% / y r$, simulating $\mathrm{R} \& \mathrm{D}$ developments in the pre-introduction period. When these technologies become competitive and production capacity is installed, endogenous technological learning takes over. Technology for carbon capture and sequestration is modelled as add-on to the base technology, using extra capital- and O\&M costs and decreasing the hydrogen production efficiency. For SMR we assumed that $\mathrm{CO}_{2}$ is only captured from the pure process stream and not from fuel combustion ( $88 \%$ of total $\mathrm{CO}_{2}$ captured). Coal gasification and POX involve only a process stream (as energy is provided within the process itself) and $95 \%$ of total $\mathrm{CO}_{2}$ can be captured. Our assumptions, based on Hendriks et al. [35] are slightly more positive than the recently published overview by Damen et al. [36], but must be seen as 'future values'. The scenario assumptions on hydrogen production technologies are based on literature data as shown in Table 2 and elaborated per scenario in Appendix B.

\subsubsection{Hydrogen end-use}

The total energy demand in TIMER 2.0 is based on assumptions on changes in population, economic activity and energy efficiency improvement. Based on mutual differences in useful energy costs, the market share of secondary energy carriers is allocated based on a multinomial logit formula (see Appendix A). We defined useful energy as the energy that is available to fulfil a demanded energy service, corrected for differences in end-use efficiency between different energy carriers. Thus, hydrogen can penetrate into five end-use markets. Another option is mixing hydrogen into the natural gas grid. Without creating difficulties for the end-user (both safety and equipment adjustment), this is only possible up to a maximum level of $5 \%$ on energy basis [35]. It can reasonably be assumed that this option is only attractive for end-use in the residential and service sectors. Similar to other end-use market allocation, the share of hydrogen in natural gas is based on relative costs via a multinomial logit with an upper constraint.

The most important assumptions on end-use are those on the cost and efficiency of fuel cells. We assume exogenous cost decline series for fuel cells. For the industry sector we assumed that solid oxide fuel cells (SOFC) will be applied $[37,38]$. For other, both stationary and mobile applications we assumed proton exchange membrane (PEM) fuel cells $[21,23,39]$. In the transport sector we consider also variations in efficiency of PEM fuel cells, as discussed in Section 2.3. We only assumed differences in technology, without taking 


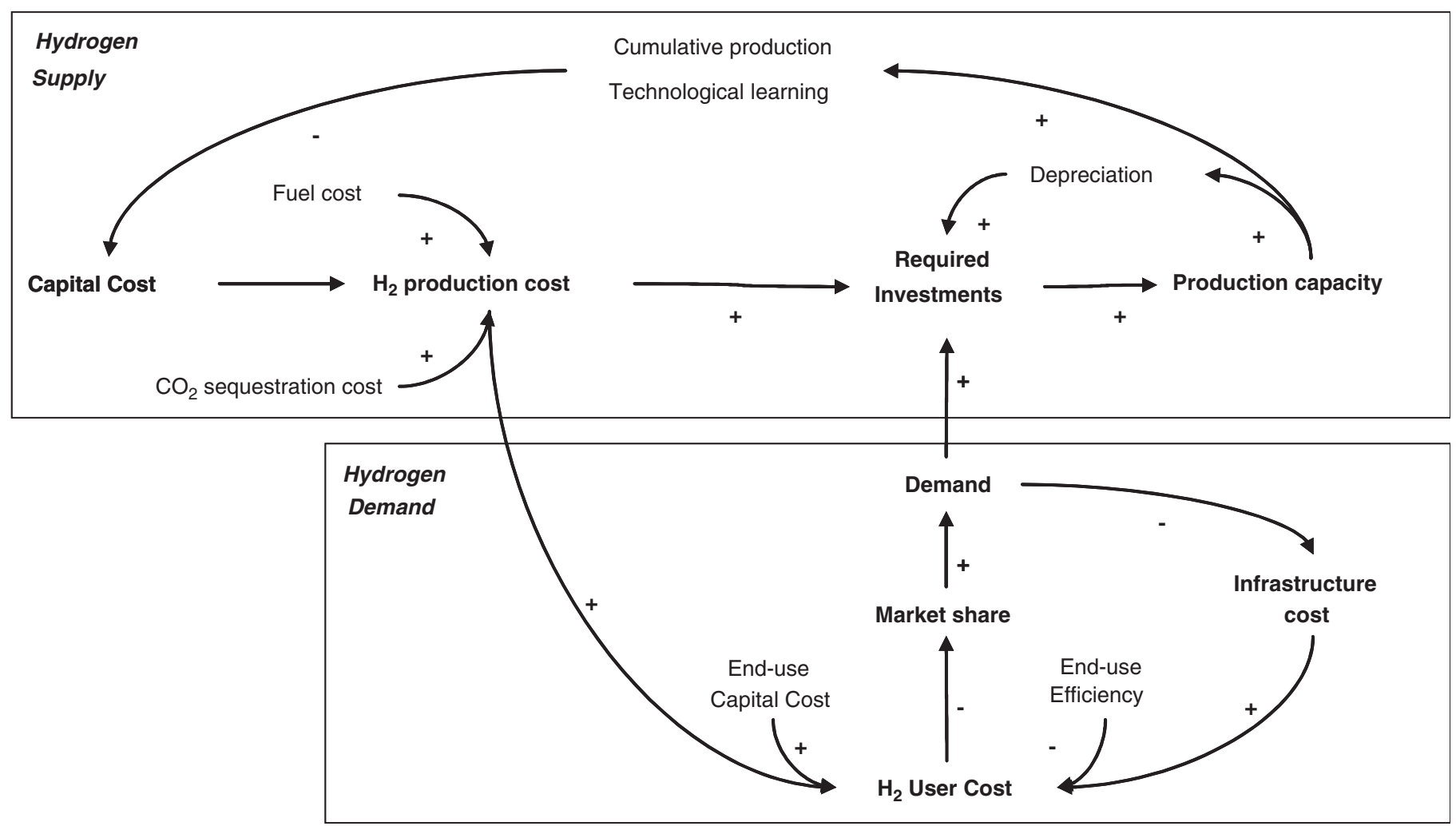

Fig. 1. Overview of the TIMER-hydrogen model. Arrows indicate influence factors or inputs for calculation.

into account the non-energy cost and differences in service characteristics (e.g. a revolutionary new vehicle design with fuel cells). The assumptions for end-use parameters are based on the ranges presented in Table 3 and can be found in Appendix B.

Although clean fuels are sometimes exempted from energy taxes, it is assumed that on the longer run taxes on energy are needed to maintain the necessary infrastructure. Therefore, in the pessimistic and intermediate scenario we assume an energy tax to be applied to hydrogen. For the transport sector we used the regional taxes on oil, in the other sectors we used the average value of taxes on other energy carriers. These taxes are exogenous and region-, time- and scenariodependent and based on IEA statistics. Depending on the region, they amount $1-15 \$ / G J$ in the transport sector and $0.2-1.5 \$ / G J$ in the other sectors. A similar approach is applied to biofuel, often a direct alternative to hydrogen. In the optimistic scenario we assumed no taxes on hydrogen, to create an optimistic case for both technology development and policy.

\subsubsection{Hydrogen distribution: the transition storyline}

Transport and distribution of hydrogen is a major issue in the transition to a hydrogen energy system. In our model we distinguish two steps in the hydrogen chain: transport and distribution. We defined the transport step as the distance from large-scale plants to residential areas or refuelling stations. Therefore, transport only applied to hydrogen produced on a large scale and includes the costs for a hydrogen transport network (e.g. pipelines or trucks). The distribution step includes the final distribution of hydrogen, e.g. the small-scale network in residential areas or the refuelling station itself. The costs of distribution are added to both large-scale and small-scale produced hydrogen (see Fig. 2).

Because the development of a hydrogen transport infrastructure is expensive, hydrogen for stationary applications will initially only be produced from small-scale SMR plants near end-use locations. It is only when hydrogen demand density rises above a certain threshold, investments in large-scale infrastructure (pipelines) will be made and stationary applications can be served by both small-scale and large-scale hydrogen plants. We assume that hydrogen demand per capita is a proxy for demand density and use, based on data from Ogden [21] and Thomas et al. [23], a threshold of 3 (optimistic) to 11 (pessimistic) GJ/cap. For the transport sector we assume that hydrogen can initially be produced at all scales, since demand is dispersed and can be provided by truck. Hydrogen mixed into the natural gas grid is assumed to be produced only from large-scale production facilities. This transition at above a certain threshold value is shown in Fig. 2 .

The transport and distribution costs for hydrogen are likely to change in time. We have linked these cost to the hydrogen demand per capita as well, since a higher hydrogen demand density leads to shorter transport distances and the transport technology will become cheaper when it is widely applied. Several options for transport of hydrogen were analysed. Based 
System I

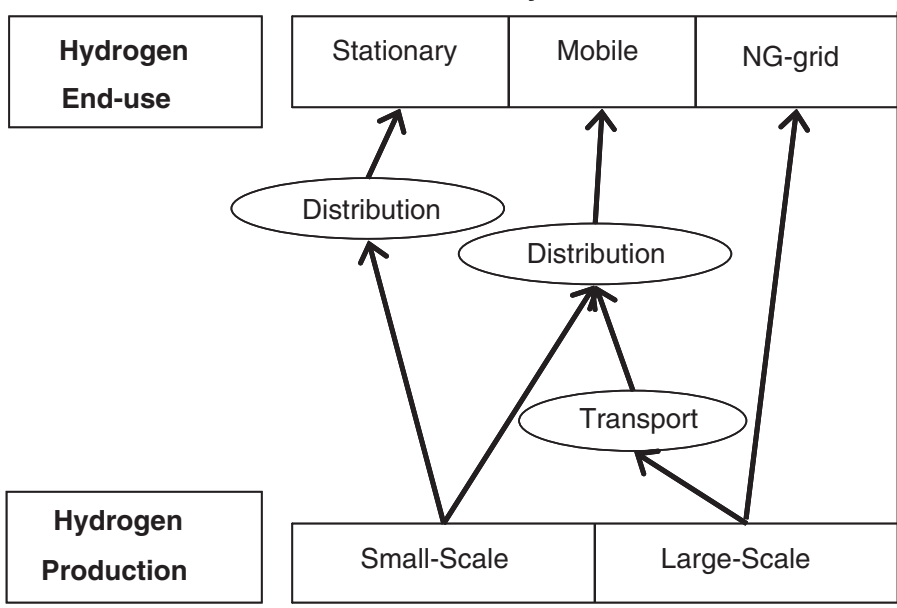

System II

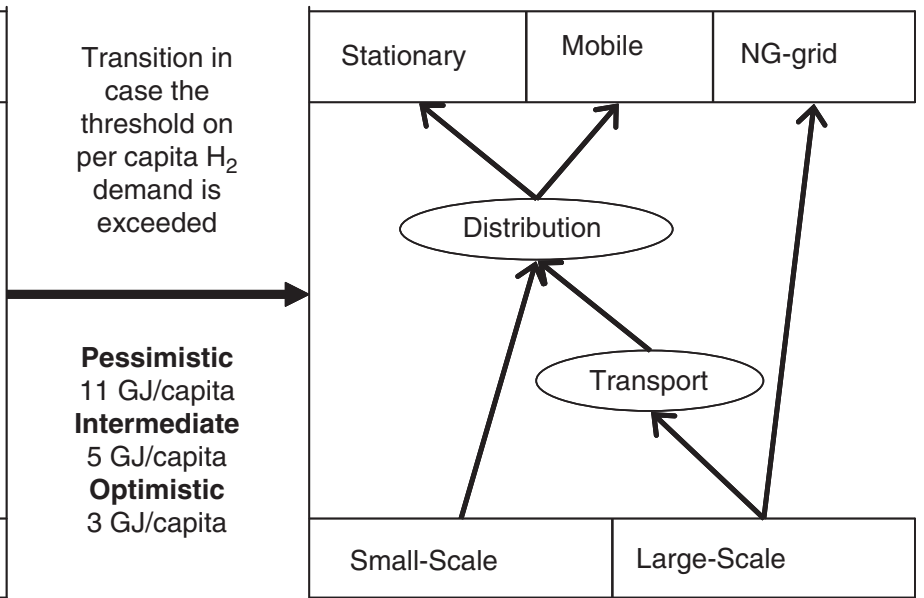

Fig. 2. Transition in transport and distribution of hydrogen.

on a spatial analysis by Mintz et al. [40] and the ranges presented in Table 4, transport costs in the pessimistic scenario decline from 12 to $6 \$ / \mathrm{GJ}$, in the intermediate scenario from 10 to $3 \$ / G J$ and in the optimistic scenario from 10 to $2 \$ / G J$.

\subsection{The TIMER-H2 scenario set}

We used values found in literature to develop pessimistic, intermediate and optimistic scenarios for hydrogen technology development. In the pessimistic set of assumptions, we describe a world in which no major hydrogen-related breakthroughs are established and transitional dilemma's, like the chicken-egg problem with demand, supply and infrastructure development, are not solved. Technologies and costs continue to improve slowly between now and 2100 towards the lower range of technology parameters found in literature (see Tables 2-4 and Appendix B). In the intermediate scenario, some promising improvements in technology are made, but after a while new boundaries are met. In particular, in the first decades of the scenario fuel cells rapidly become cheaper. However, after this initial break-through, further progress slows down. In the production phase, no major new costs reduction are achieved-and partly because the major development of fuel cell markets does not occur - production capacity stays limited and hydrogen production technology does not learn as much as was hoped for. Some hydrogen distribution infrastructure is developed for the transport sector, but apart from few niche markets transition is costly. In this scenario, technologies improve to the lower range of technology estimates by 2050 but improve more slowly in the second half of the century towards more intermediate values. Finally, in the third optimistic scenario, breakthroughs in hydrogen technology are realised and transitional issues are vigorously solved. Fuel cells are mass produced at low cost, hydrogen production technology becomes cheaper and better through learning and distribution infrastructure is developed rapidly at low costs. In this scenario, technologies are assumed to improve rapidly to reach an intermediate range by 2030 and the most optimistic values in literature in 2100. We assumed these technology improvements as an exogenous process, and did not take into account any related costs, for instance R\&D investments. It should be noted that we vary assumptions on the hydrogen technology itself and that developments in other technologies (e.g. batteries, hybrid-vehicles) are assumed similar in all scenarios.

These three sets of assumptions are combined with the TIMER 2.0 B2 scenario, as described in Section 3.2. One additional dimension is added: the existence of CP. All scenarios were run in a default case without $\mathrm{CP}$ and under the constraint that greenhouse gas concentrations will be stabilised at 450 ppmv $\mathrm{CO}_{2}$-equivalent. While different emission profiles exists to go to $450 \mathrm{ppmv} \mathrm{CO}_{2}$-equivalent, we have used an emission path from the FAIR model, as described in Refs. $[41,42]$. This profile can be interpreted as median scenario in timing, without major overshoot. Recently published studies on the probability distribution of climate sensitivity suggest that such low stabilisation levels are required in order to have a reasonable chance of reducing global mean temperature change to $2^{\circ}$ above pre-industrial levels [43]. For this study, this ambitious stabilisation target (compared to most literature published on mitigation scenarios) is chosen to have a clear signal from CP on the development of the energy system. One additional scenario is run in case of $\mathrm{CP}$ to explore specifically the role of excluding CCS in the optimistic hydrogen scenario (as CCS technology costs and acceptance are also uncertain). This implies that the model is run for nine different cases. First of all, the B2 baseline and the three hydrogen variants without $\mathrm{CP}$ : the $\mathrm{H}_{2}$ Pessimistic case (NoCP Pes), intermediate case (NoCP Int) and optimistic case (NoCP Opt). As we found that under the NoCP Pes scenario no penetration of hydrogen occurs, this scenario is actually equal to the baseline (and is thus used for this purpose throughout the paper). The second scenario set is identical but now with a CP constraining the $\mathrm{CO}_{2}$-equivalent concentration to $450 \mathrm{ppmv}$ by 2100: $C P P e s$, CP Int and CP Opt. The last case is the one without the possibility of carbon capture and sequestration (CP Opt NoCCS). 


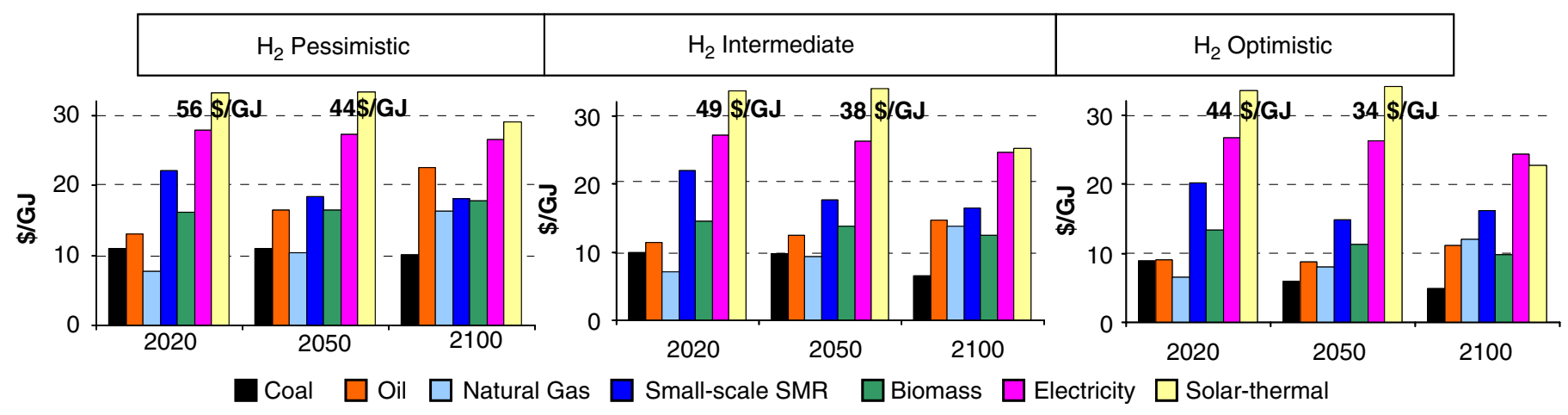

Fig. 3. Hydrogen production cost before transport and distribution and before tax, for several technologies in OECD Europe and without climate policy.

\section{Results}

\subsection{Scenarios without Climate Policy (NoCP)}

\subsubsection{Hydrogen production}

Fig. 3 shows the costs of the various options to produce hydrogen in OECD Europe in the three scenarios without CP. In principle, for all options there is a downward pressure on costs as a result of learning by doing. In terms of the differences between the intermediate and optimistic scenario, a higher progress ratio and lower starting values for investment costs under the optimistic scenario contribute to making hydrogen production more competitive than under the intermediate scenario. This in turn leads to more investments, driving technologies further down the learning curve. By the end of the century the observed cost differences are for more than half caused by the differences in cumulative capacity; the costs differences as a result of different progress ratios play a smaller role. In addition to the decrease of capital costs from learning effects, total production costs may increase as feedstock costs (in particular, oil and natural gas) are expected to increase over the century.

Fig. 3 shows that hydrogen production from coal and natural gas is for most of the century the cheapest option. Initially hydrogen can be produced from large-scale SMR at about 5-10 \$/GJ. These costs remain more-or-less constant in the first 50 years, as a result of decreasing investment costs on the one hand and increasing natural gas prices on the other. The latter effect dominates by the end of the century, raising production costs to over $10 \$ / G J$ in all scenarios. This means that in the second half of the century, hydrogen production from coal is the cheapest technology, at costs declining to about $5 \$ / G J$ in the optimistic scenario. The small-scale methane reform option has relatively high production costs as a result of unfavourable economies of scale and lower efficiency. Nevertheless, this option may well be cost-effective in the residential/services sector where the hydrogen can be produced at the demand site without additional transport costs. The options to produce hydrogen from oil, electricity and solar-thermal are hardly competitive in any to the scenarios without CP. Hydrogen produced from biomass is among the low costs options in the second half of the century in the intermediate and optimistic case.
Hydrogen production is shown in Fig. 4 (upper graphs). Hydrogen starts to be produced in the second half of the century-where under some of the scenarios hydrogen becomes competitive (see further in this section). In the pessimistic case, hydrogen remains too expensive-and thus there is no consumption. The production shares shown in Fig. 4 do obviously directly reflect the costs shown in Fig. 3. The hydrogen production in the scenarios is almost exclusively based on coal and natural gas.

Of course, hydrogen production cost and hence market prices differ across regions due to differences in coal and gas production costs, technology level and trade opportunities. In the Middle East and the Former Soviet Union (FSU), abundant natural gas resources lead to relatively low costs for natural gas-based routes even in the longer term. Regions with large coal resources and less natural gas, in particular East Asia, South Asia and Southern Africa, have the coal-based route as the cheapest hydrogen production technology already at the beginning of the century.

Interregional fuel trade is possible in the TIMER-model if there is a large enough price differential [28]. Yet, in none of our scenarios significant amounts of hydrogen are traded between regions. This result is also found by Baretto et al. [13] and is due to the high costs of hydrogen transport over long distances-in our model simulations $80 \%$ higher than of natural gas transport [21]. Besides, a region needs a large-scale hydrogen infrastructure before it can start importing or exporting. However, hydrogen trade causes a significant increase in international coal-trade compared to the baseline scenario, in particular towards OECD Europe, South East Asia and South America.

\subsubsection{Hydrogen end-use}

The price of hydrogen for end-users varies per region and sector, due to differences in production technologies, transport and distribution cost and different energy taxes. Fig. 5 shows a breakdown of the hydrogen price in the transport sector of OECD Europe. In our results, transport is the first sector where hydrogen penetrates the market. The figure shows that production costs represent about $50 \%$ of all end-use costs (excluding taxes). The other half is formed by transport and 


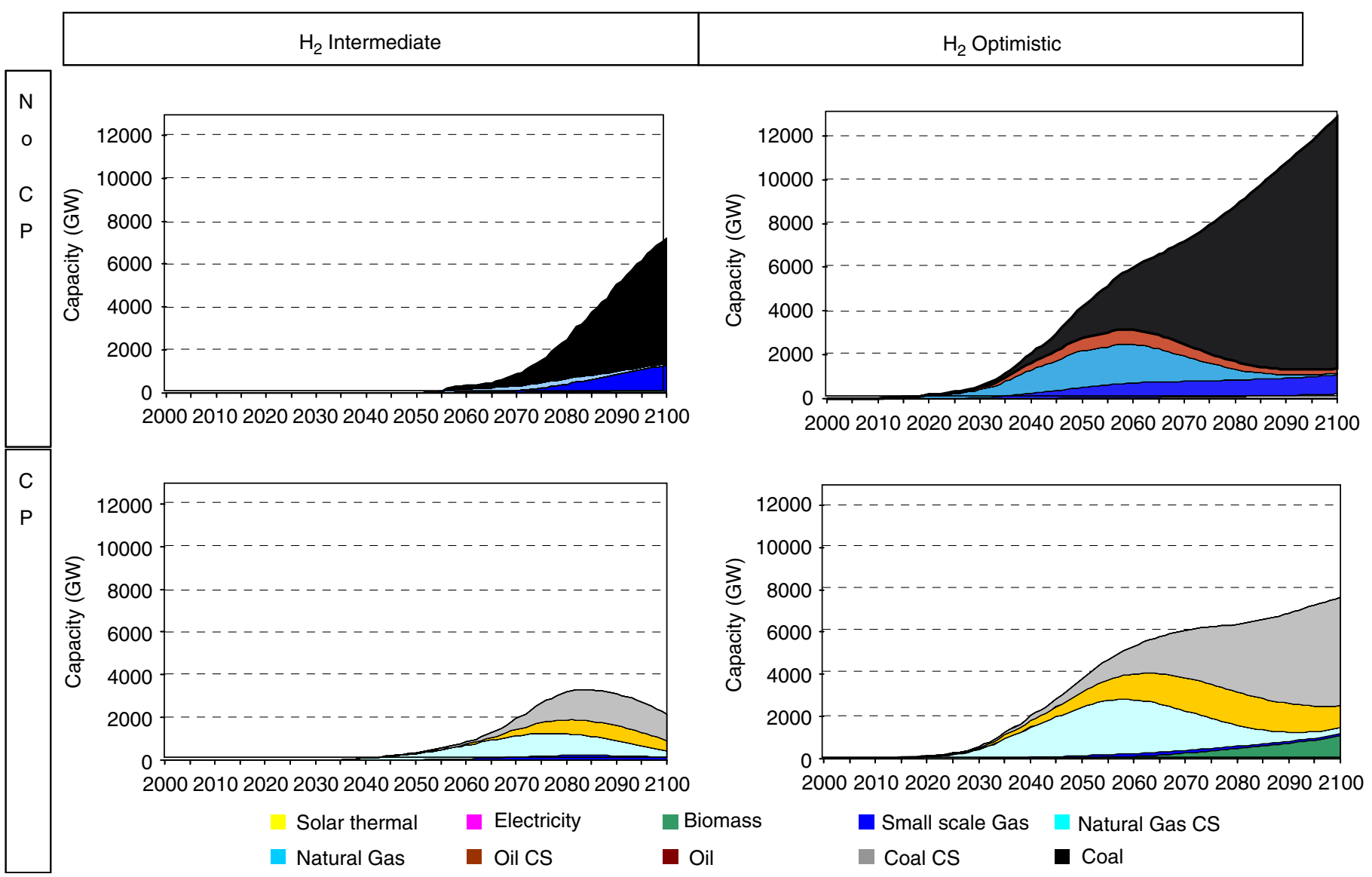

Fig. 4. World hydrogen production capacity for the intermediate and optimistic hydrogen scenarios with and without climate policy (CP). With pessimistic assumptions on hydrogen technology and cost, no penetration occurs.

distribution cost (again excluding taxes). The figure also shows that end-use taxes could represent a major share of end use prices. Globally compared, energy taxes are highest in the transport sector of OECD Europe, which causes a significant difference between the intermediate (tax equal to oil) and optimistic (no tax) scenarios. In all other regions and sectors these differences are much smaller. We found that, although the energy tax has a significant impact on the hydrogen cost, it does not influence the penetration of hydrogen in the Pessimistic scenario.

The direct alternative of hydrogen in the transport sector, oil, has an end-use price of about $15 \$ / G J$ in the OECD European transport sector. However, because hydrogen is more efficiently applied in fuel cells, the useful energy price of hydrogen is in the NoCP Int scenario 30\% higher than oil in 2020, about equal in 2050 and $30 \%$ lower in 2100 . In the NoCP Opt scenario, useful energy cost hydrogen in the transport sector of OECD Europe are 30\% lower than oil in 2020 and $80 \%$ in 2100 .

Thus, with our assumptions, hydrogen is in the NoCP Int scenario only competitive in the transport sector, although some hydrogen is also mixed into the natural gas grid and thus indirectly delivered to the residential and service sector (Fig. 6 upper left). In the residential and service sector, hydrogen cannot compete in the combined heat-and-power (CHP)/fuel cell application with natural gas and electricity. In the $\mathrm{NoCP} O p t$ scenario, hydrogen technology improves so much that it penetrates not only the transport but also the residential and service sector markets (Fig. 6, upper right). Largescale use for transport takes off around 2015 and is completed at the end of the century. In the built environment hydrogen becomes globally a major final end-use carrier by the end of the century, providing $45 \%$ of the residential and $35 \%$ of the services sector-although electricity (24\% and 57\% resp.) and natural gas (7\% and $4 \%$ resp.) keep a significant market share as well. Even now, however, there is no large-scale penetration of hydrogen in the industry sector as it can still not compete with coal, biomass and to some degree oil in this market.

A closer look at the results indicates that OECD Europe, Eastern Europe and Japan are the first regions where hydrogen is introduced in all scenarios with hydrogen penetration. This early introduction of hydrogen can be explained from higher energy prices and taxes in these regions, which are not levied on hydrogen in the NoCP Opt scenario and are thus an implicit subsidy for hydrogen. At the end of the 21 st century the worldwide penetration of hydrogen into final energy consumption is about $40 \%$ in the optimistic scenario, with $50-60 \%$ in 


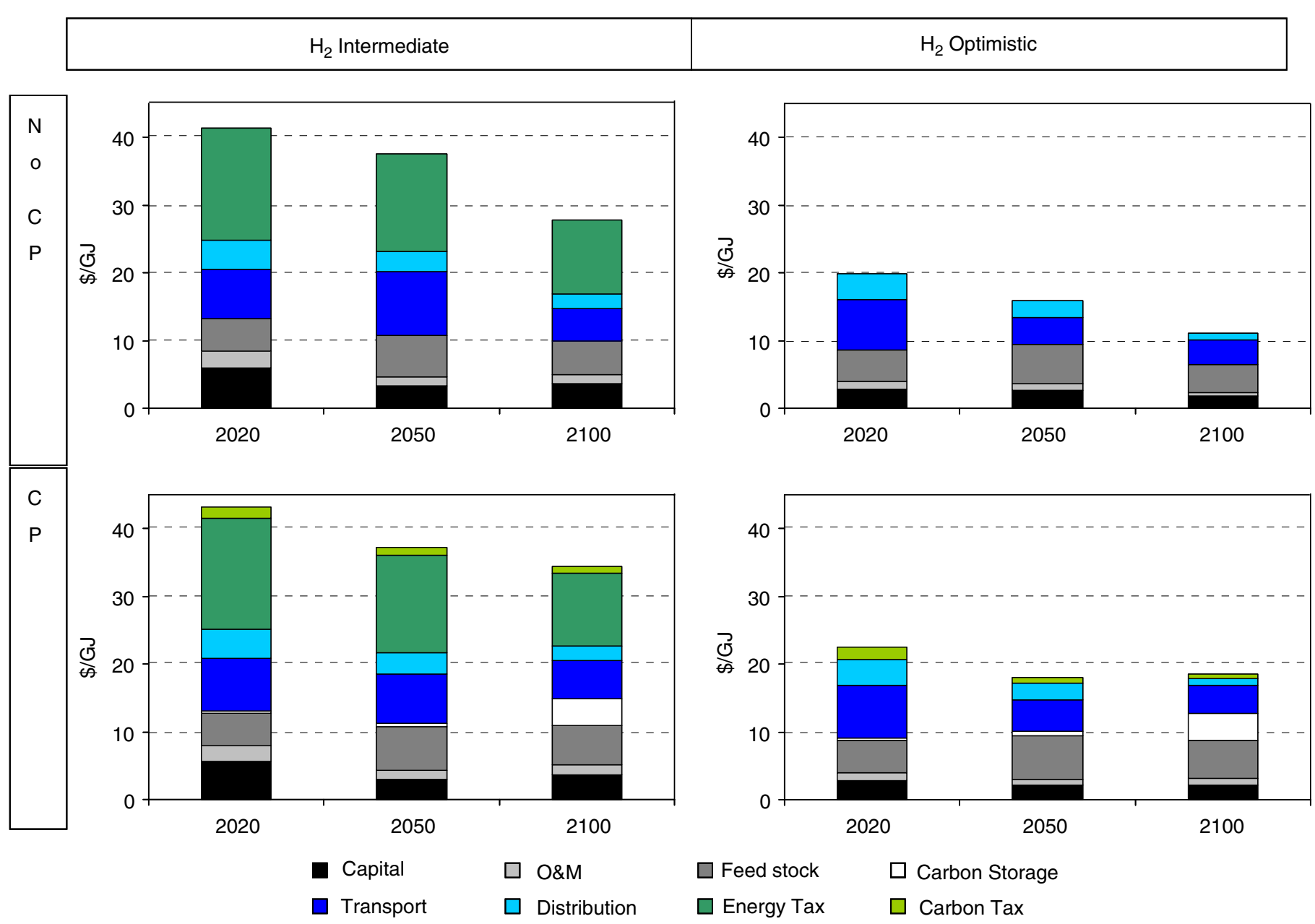

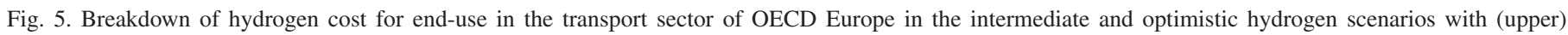
and without (lower) climate policy (CP). With pessimistic assumptions on hydrogen technology and cost, no penetration occurs.

Canada, OECD Europe and Japan and less than $35 \%$ in Africa and South Asia. Because hydrogen has in the intermediate scenario a higher price and thus is less competitive viz-à-viz other options which are introduced in response to rising oil and gas prices, penetration is significantly less: worldwide $20 \%$ in 2100 , with 25-30\% in Canada, USA, OECD Europe and Oceania and less than $15 \%$ in Africa.

\subsubsection{Primary energy use}

The simulation experiments suggest that the introduction of hydrogen can have important strategic and environmental consequences for the world energy system. It can reduce local emission as it is a clean fuel, in particular urban pollution from transport. It may also shift energy trade patterns as it can substitute for oil while being produced from coal or natural gas. However, the resulting primary energy use may for this very reason worsen the problem of climate change. As Fig. 7 shows, coal use is in the NoCP scenarios with hydrogen significantly higher than in the baseline scenario (upper middle and right vs. upper left graph). It also accelerates the use of natural gas, causing a more rapid depletion and subsequent decline in use of this relatively low-carbon fuel. Hydrogen thus brings a new golden era for coal: by 2100 coal satisfies $60 \%$ of world energy demand.

What are the consequences of such a scenario? First, it presumes that such vast amounts of coal-in the order of 28 billion ton per year, half of which for hydrogen - can be produced and processed. In the model, this production mainly occurs in the USA and East Asia. Obviously, coal mining and transport at this scale will cause huge mass flows with environmental consequences. Second, it has consequences for $\mathrm{CO}_{2}$ emissions. In fact, until 2080 the differences in carbon emission between the pessimistic $\left(\right.$ no $\left.\mathrm{H}_{2}\right)$, intermediate and optimistic case are small because both coal and natural gas use increase at the expense of oil (see Fig. 8, coal with a higher carbon content and gas with a lower carbon content). However, in the scenario without hydrogen penetration emissions start to decline after 2080 as a result of the growth of non-carbon options such as nuclear, wind/solar, biomass. Interestingly, a successful hydrogen penetration implies, without $\mathrm{CP}$, that as a result of increased coal use, carbon emissions keep growing in the last part of the 21 st century. Thus, $\mathrm{CO}_{2}$ emissions of the intermediate and optimistic scenarios are, respectively, $6 \%$ and $15 \%$ higher than the baseline scenario. 


\begin{tabular}{|c|c|}
\hline $\mathrm{H}_{2}$ Intermediate & $\mathrm{H}_{2}$ Optimistic \\
\hline
\end{tabular}
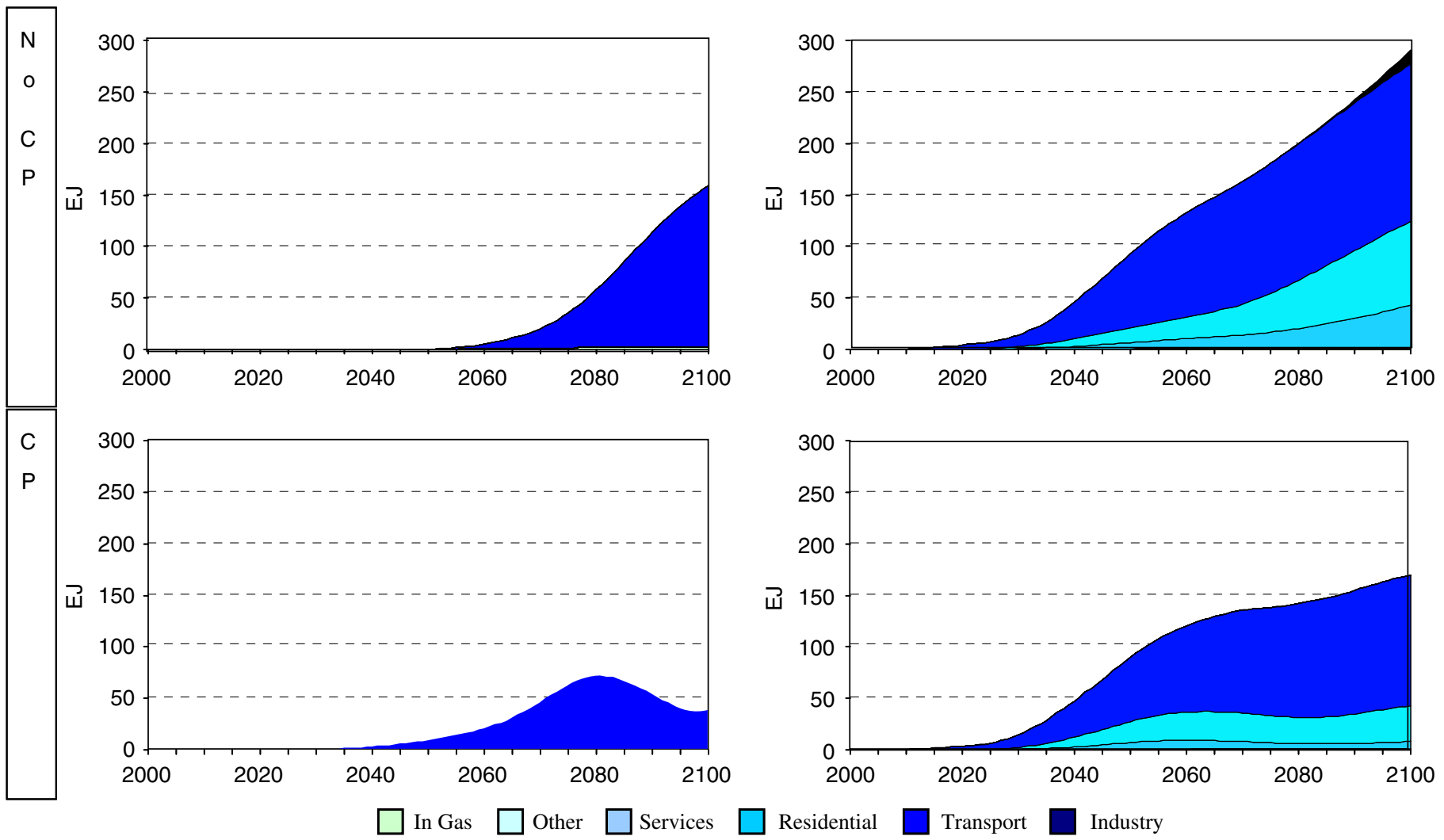

Fig. 6. World hydrogen end-use for the five sectors in the intermediate and optimistic hydrogen scenarios with (upper) and without (lower) climate policy (CP). With pessimistic assumptions on hydrogen technology and cost, no penetration occurs.

\begin{tabular}{|c|c|c|}
\hline $\mathrm{H}_{2}$ Pessimistic & $\mathrm{H}_{2}$ Intermediate & $\mathrm{H}_{2}$ Optimistic \\
\hline
\end{tabular}
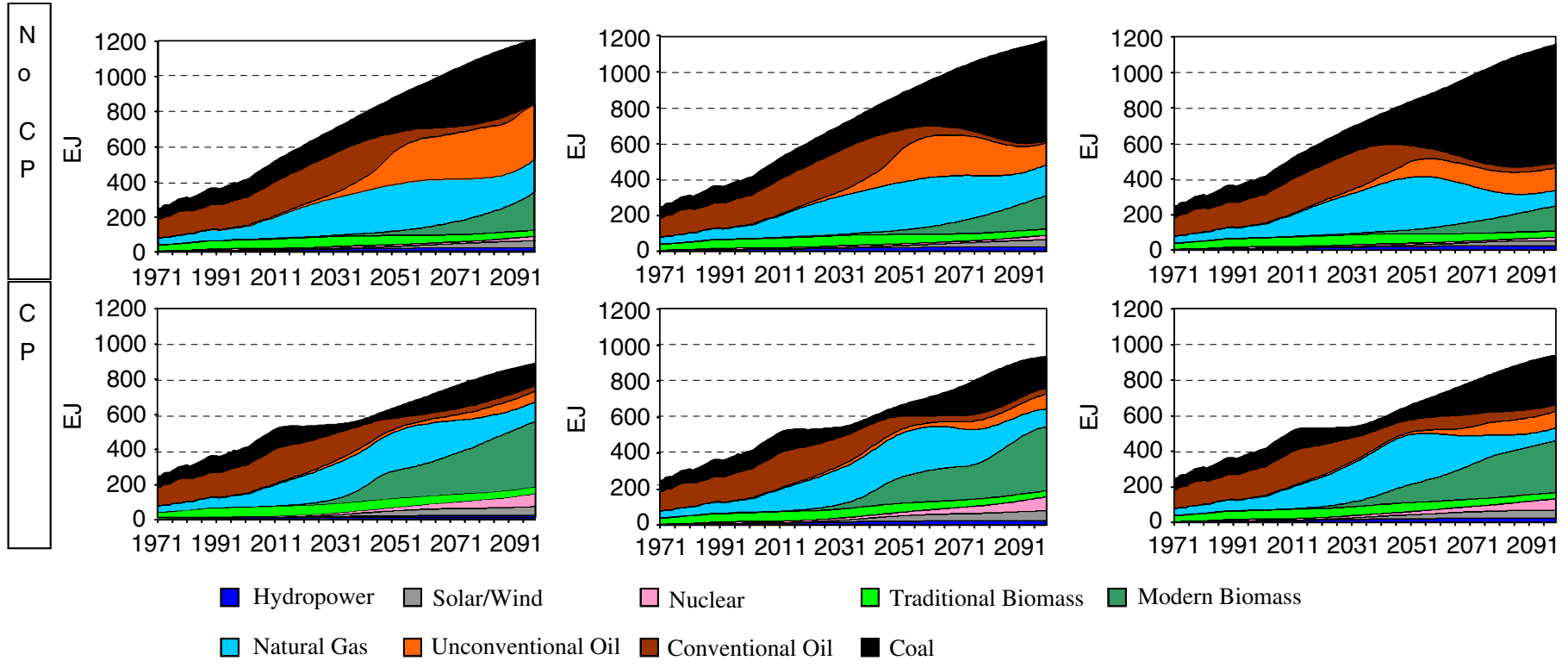

Hydropower $\square$ Solar/Wind

$\square$ Natural Gas $\square$ Unconventional Oil $\square$ Conventional Oil $\quad$ Coal

Fig. 7. World primary energy use in all hydrogen scenarios with (upper) and without (lower) climate policy (CP). With pessimistic assumptions on hydrogen technology and cost, no penetration occurs. 


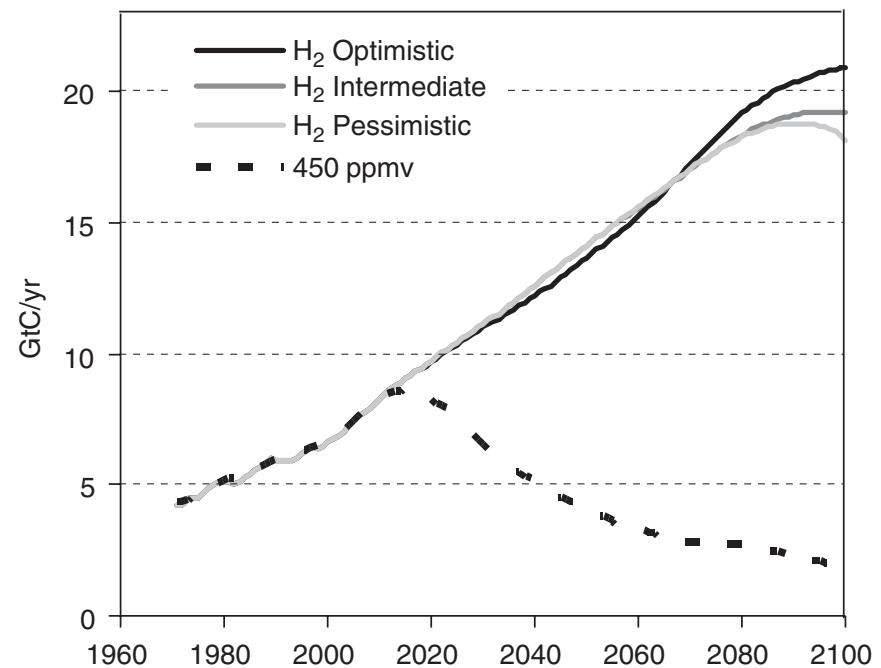

Fig. 8. Global $\mathrm{CO}_{2}$ emission from all hydrogen scenarios without climate policy. With pessimistic assumptions on hydrogen technology and cost, no penetration occurs

\subsection{Scenarios with Climate Policy $(C P)$}

To explore the relationship between hydrogen-based energy systems and $\mathrm{CP}$ in more detail, we have simulated three additional scenarios in which the $\mathrm{CO}_{2}$-equivalent concentration is stabilized at 450 ppmv by the end of the century. This is an ambitious goal and it requires the introduction of a rapidly increasing carbon tax. The carbon tax serves in the TIMER model simulations as a generic way to stimulate all kinds of measures to reduce carbon emissions - all elements of more detailed CP formulations, such as increasing energy efficiency, stimulating renewable and nuclear energy options and the introduction of CCS [44].

One of the most striking results is that less hydrogen is used in the scenarios with CP. This can be explained from two dynamics: first, due to energy savings the total demand for energy is lower with CP (see e.g. Fig. 7) and second, hydrogen now competes directly with biofuels. As the costs of hydrogen rise with $\mathrm{CP}$, because of CCS technology and rest-emissions, the costs of biofuel stay the same. In the $C P$ Int scenario, the share of biofuel in the transport sector decreases at the expense of hydrogen. In the CP Opt scenario hydrogen is pushed aside by biofuels in the built environment, as it stays as the main energy carrier in the transport sector.

Fig. 9 shows the carbon tax (or carbon-price) profiles which are required to force the carbon emissions along a $450 \mathrm{CO}_{2}$ equivalent concentration profile. Our results show that hydrogen introduction can actually play an important role in CP (as suggested by the large differences between scenarios). The reason is that once the energy system (and in particular the transport sector) has hydrogen penetration, the additional costs to produce hydrogen from fossil fuels with CCS are limited compared to hydrogen production without CCS. Without hydrogen, reducing $\mathrm{CO}_{2}$ emissions to very low levels is complicated by the high-cost reductions in the transport sector.

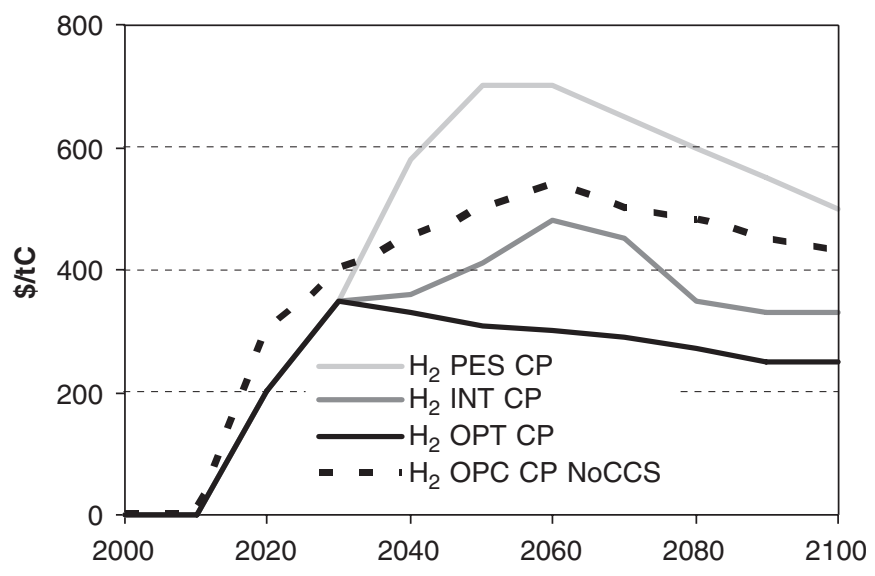

Fig. 9. Global carbon price in the hydrogen scenarios with climate policy. With pessimistic assumptions on hydrogen technology and cost, no penetration occurs.

In the $C P$ Int scenario, hydrogen is produced from fossil fuel CCS technologies. Hydrogen costs in end-use remain competitive and the world can by the end of the century use twice as much coal as at present despite the climate constraint (Fig. 7, lower middle graph). This leads to the significantly lower carbon tax (Fig. 9) which is also reflected in the low additional costs of $\mathrm{CP}$ in hydrogen end-use prices (Fig. 5, lower graphs). The favourite hydrogen-based carbon emission reduction options are first gas- and then coal-conversion with CCS (Fig. 4, lower left graph). It the CP Opt scenario the hydrogen-coal-CCS chain is being introduced at an exceedingly large scale. Primary energy use is for some $30 \%$ based on coal (Fig. 7, lower right graph) which is converted to hydrogen while capturing and storing in the order of 4.5 billion ton of carbon per year. The hydrogen is used for over $75 \%$ in the transport sector (Fig. 6, lower right graph). This can be induced by a rather modest carbon tax, as is seen from Fig. 9. The way to use hydrogen while at the same time reducing carbon emissions is the large-scale conversion of natural gas into hydrogen with CCS, starting already around 2020, and gradually switching feedstock from gas to oil and from 2050 onwards to coal (Fig. 4, lower right graph).

Evidently, this expansion of the hydrogen economy hinges on the availability of CCS options at the presumed declining cost levels used in this simulation. It also presumes that the associated risks are acceptable in those regions where it will occur at the largest scale: USA, East Asia, OECD Europe and South Asia. As CCS plays such a dominant role in our results, while the technology itself still needs to be tested at large scale, we have also simulated a scenario in which CCS is assumed to be not available. As one would expect, there is now a rapid growth in the use of non-carbon options for electric power generation such as nuclear and wind/solar (Fig. 10, right graph). At the same time the use of hydrogen from biomass in the transport sector increases rapidly because the cost-effective options of hydrogen from fossil fuels with CCS is no longer available (Fig. 10, left graph). Hydrogen production from fossil energy carriers becomes much less attractive. Only hydrogen from nat- 

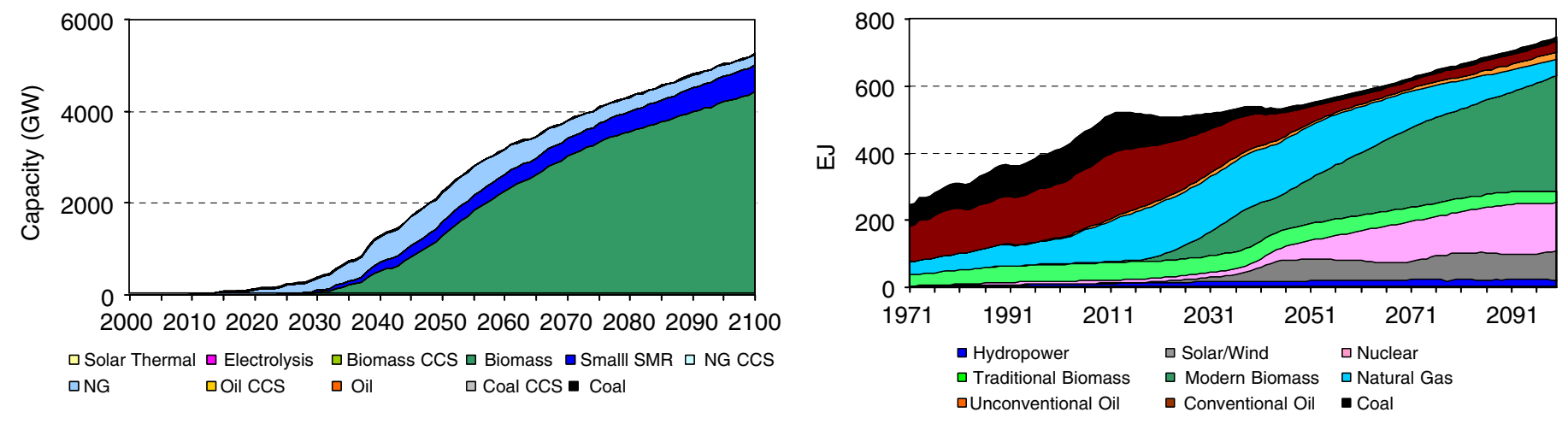

Fig. 10. Overview of the optimistic hydrogen scenario with climate policy and without CCS: global hydrogen production capacity (left) and global primary energy use (right).
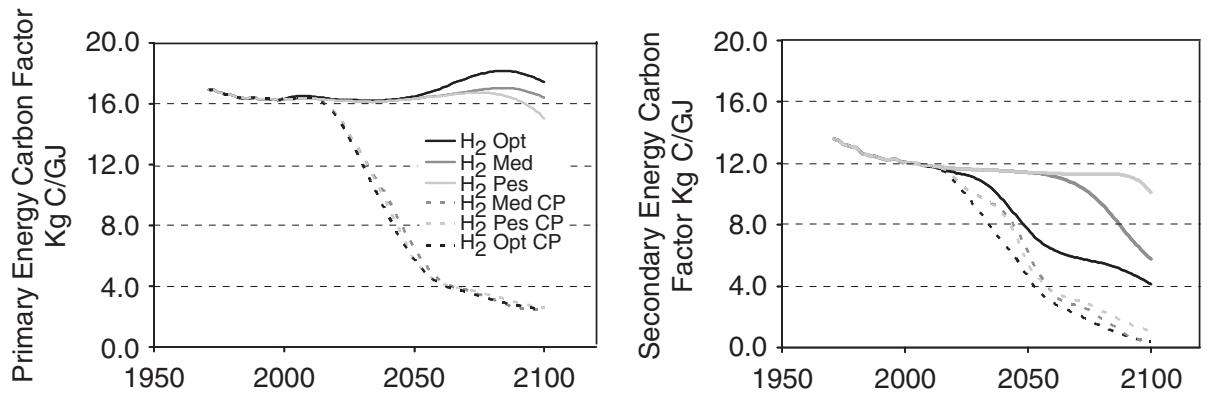

Fig. 11. Global primary energy carbon factor (left) and secondary energy carbon factor (right) for all hydrogen scenarios with and without climate policy.

ural gas is competitive in some markets and starts even much earlier now, around 2020, than in the other scenarios. Later on, also the SMR option becomes interesting because its disadvantage with regard to $\mathrm{CCS}$, namely that a costly $\mathrm{CO}_{2}$ distribution network is required, does not matter anymore. As a result, world hydrogen demand is lower than in the other optimistic scenario variants and world coal use nearly vanishes.

\subsection{Impact of hydrogen on future energy systems}

\subsubsection{Carbon intensity}

The results in the previous section show that the environmental consequences of hydrogen use for carbon emissions are ambivalent. Without $\mathrm{CP}$, carbon emissions are likely to increase with hydrogen use but at the same time it creates relatively cheap carbon mitigation options. Fig. 11 compares the influence of hydrogen on carbon intensity of primary and secondary energy flows. Without $\mathrm{CP}$, the primary carbon intensity increases with hydrogen use, as coal is substituting oil and natural gas. Secondary energy carbon intensity decreases with hydrogen use as hydrogen, with zero carbon content, substitutes for oil. With CP, primary energy intensity is similar for all scenarios, because carbon emissions are constrained to a $450 \mathrm{ppmv}$ stabilisation scenario. Secondary energy carbon intensity still decreases by the use of hydrogen.

This finding is in contrast with Barreto et al. [13], who developed a sustainable hydrogen scenario with a strongly decreas- ing primary carbon intensity, due to production of hydrogen from solar thermal and natural gas. However, it is in agreement with the scenarios described in Edmonds et al. [14], who also found that coal is an attractive hydrogen feedstock without CP.

\subsubsection{Configuration of the future hydrogen energy system}

In Section 2.2 we described three main configurations with respect to future hydrogen production that can be identified from the literature: large-scale production of hydrogen from fossil sources, mainly coal and natural gas; a fossil-based hydrogen system with CCS; and renewable hydrogen production, based on biomass gasification, direct solar thermal hydrogen production and electrolysis from solar or wind electricity. Using the optimistic scenario, we were able to simulate three variants of these configurations. The variant without $\mathrm{CP}$ produces hydrogen from coal; the variant with $\mathrm{CP}$ produces hydrogen from coal with CCS or, if CCS is not available, from biomass and natural gas. We then analysed the total system costs, defined as the annuitised total capital costs in the energy system relative to the baseline scenario. The results are plotted against the penetration of non-carbon options in primary energy (Fig. 12, left part) and hydrogen in secondary energy (Fig. 12, right part).

Without $\mathrm{CP}$, the line coincident with the $x$-axis represents the baseline scenario, which has about $30 \%$ contribution from non-fossil sources (wind, solar, nuclear, modern biomass) by 2100 and no hydrogen penetration. With optimistic assumptions 


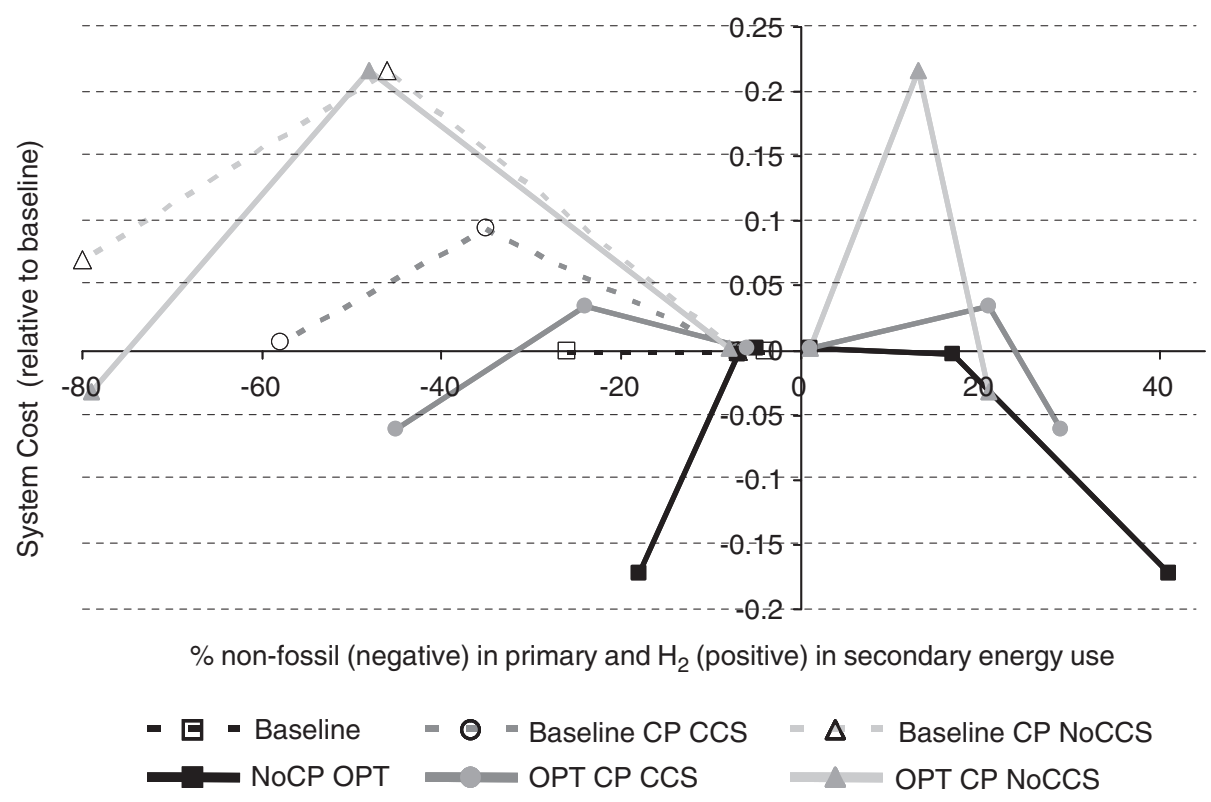

Fig. 12. Comparison of hydrogen use in several long-term studies. Studies focusing only on the transport sector are included under the assumption that this sector counts for $30 \%$ of the total secondary energy use.

(NoCP OPT), hydrogen could penetrate the global secondary energy market up to $40 \%$ by 2100 , at $17 \%$ lower overall energy system costs and almost halving the contribution of nonfossil sources. With a climate constraint, the baseline scenario (Baseline CP CCS) shows an increased contribution from nonfossil sources, to almost $60 \%$ by 2100 and an increase of costs compared to the baseline without CP. In this case, the introduction of hydrogen again decreases the share of non-fossil energy sources and lowers the overall energy system costs with $8 \%$ by 2100 . Evidently, if the CCS option is not available for whatever reason, the market penetration of non-fossil sources increases further and energy system costs increase significantly for the baseline scenario (Baseline CP NoCCS). However, combined with optimistic hydrogen assumptions (OPT CP NoCCS), the share of non-fossil energy sources is not influenced and costs decrease below the non-climate baseline scenario by 2100 .

\section{Comparison with other studies}

As has been emphasised throughout this paper, there are many uncertainties in any assessment of the prospects of hydrogen as an energy carrier. Some of these have been addressed by using a range (optimistic-intermediate-pessimistic); others are dealt with in the form of scenarios. A third way is to compare our results with studies done by others-although one cannot exclude collective bias. We chose the fraction of hydrogen in secondary energy markets over time and worldwide as the indicator for comparison (Fig. 13). Included are only scenarios which expect any role at all for hydrogen, which in itself is a biased representation. Nevertheless, some lessons can be drawn.

The fraction of secondary energy used in the form of hydrogen is in our optimistic scenario higher than in the scenarios

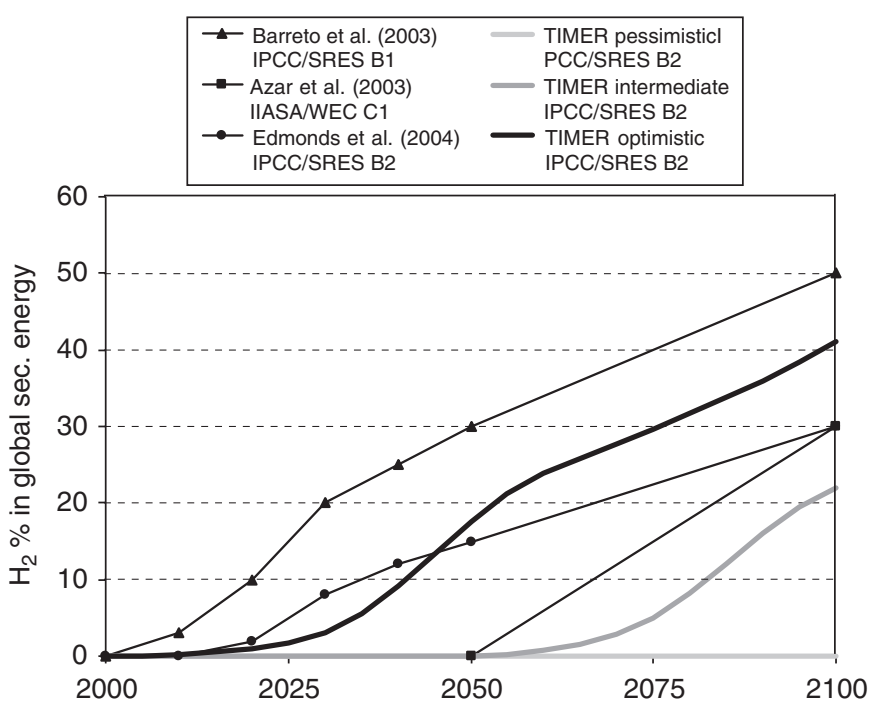

Fig. 13. Comparison of hydrogen use in several long-term studies. Studies focusing only on the transport sector are included under the assumption that this sector counts for $30 \%$ of the total secondary energy use.

by Edmonds et al. [14] and Azar et al. [12], but still lower than in the one by Barreto et al. [13]. If we relax the optimistic assumptions on hydrogen costs, our simulated pathway drops even below the scenarios of Edmonds et al. [14] and Azar et al. [12].

A more detailed comparison with the study by Edmonds et al. [14] suggests several similarities. Although in TIMER the hydrogen energy system initially develops slower than in the MiniCAM model, both indicate coal gasification as the main hydrogen production technology-and both therefore calculate an increase in $\mathrm{CO}_{2}$ emissions and point at the enhanced 
potential role of CCS as the main consequence of hydrogen in mitigation scenarios. The study by Barreto et al. [13] is much more optimistic on the future role of hydrogen in the global energy system. This may be a consequence of the assumed high environmental awareness in the $\mathrm{B} 1-\mathrm{H}_{2}$ scenario that they developed. Another difference is the application of micropower CHP systems from mobile fuel cells, an option not included in our simulations. A comparison with Azar et al. [45] is more difficult, as their model simulates the transport sector only. Yet, their results for the transport sector are similar to those in our optimistic scenario and project a major shift from oil to hydrogen in the second half of the century.

\section{Conclusion}

In this analysis we present results of model-based explorations to the role of hydrogen in future energy systems under various assumptions on technology development and CP. Contrary to existing literature, we included a wide range of uncertainties in our scenarios, resulting in a broader overall context that explains existing studies from a different perspective. The results lead us to the following conclusions.

- Hydrogen will probably not play an important role before mid-21st century in the world energy system, neither with nor without climate policy. Thereafter it can become a major secondary energy carrier but only under optimistic assumptions. The transport sector is the key market; even under less optimistic assumptions hydrogen might play a role here. Air pollution from combustion of fossil fuels might be an additional motivation to use hydrogen in the transport sector. The best prospects are in OECD Europe and Japan, where energy prices are relatively high due to high taxes and low indigenous resources. The build-up of a large-scale hydrogen infrastructure, in particular for transport, plays a crucial role.

- Coal- and natural-gas-based technologies seem to be economically most attractive for hydrogen production, with and without CP. In particular coal gasification and SMR are cost-competitive. Partial oxidation of oil, biomass gasification, electrolysis and solar thermal hydrogen production are more expensive and play consequently a minor role. Under carbon constraints, the fossil-fuel-based hydrogen production technologies are still the most attractive combined with CCS; if CCS is not available, the preferred hydrogen path shifts towards biomass and natural gas.

- Three typical configurations in future hydrogen production can be distinguished in different scenarios. We reproduced the three typical configurations also found in the literature and found them related to assumptions on $\mathrm{CP}$ and technology availability. Without $\mathrm{CP}$, we found large-scale hydrogen production from fossil sources (like Edmonds et al. [14]); with $\mathrm{CP}$, we found large-scale hydrogen production from fossil sources with CCS (like Edmonds et al. [14]); in case of CP but with CCS not available, we found the development of a renewable energy-based hydrogen production system (like Barreto et al. [13]).

- Without $\mathrm{CP}, \mathrm{CO}_{2}$ emissions from energy systems with hydrogen are likely to be higher than those of systems without hydrogen. The reason for this result is that hydrogen is produced at the lowest cost from coal-hence, coal will be a substitute for oil in the primary energy supply and deliver hydrogen as a secondary energy carrier, particularly for the transport sector.

- Energy systems with hydrogen respond more flexibly and at lower marginal abatement cost to CP. The reason for this is related to the previous conclusion: the use of hydrogen provides new and presumably cheap carbon emission reduction options in the form of centralised CCS.

\section{Acknowledgements}

The authors thank the other members of the IMAGE 2.2 team for their contributions to this paper. We further thank Leonardo Barreto, Ivo Bouwman, Arend de Groot and Joost Quakernaat for their advice on hydrogen energy systems.

\section{Appendix A. Key characteristics of the TIMER 2.0 model}

The formula that allocates the market share among energy carriers in the sub-models of TIMER 2.0 is the multinomial logit model:

$\operatorname{IMS}_{i}=\frac{\mathrm{e}^{-\lambda C_{i}}}{\sum \mathrm{e}^{-\lambda C_{i}}}$.

$\mathrm{IMS}_{i}$ is the indicated share of total investments for energy carrier $i, \lambda$ is the so-called logit parameter that determines the sensitivity of markets to price changes and $C_{i}$ is the cost of energy carrier $i$. The latter may include other factors than the price of the energy carrier, such as premium factors and cost increases due to carbon taxes. In this analysis we used no premium factors on hydrogen. It should be noted that the multinomial logit is used to determine shares in new investment, which implies that the actual market shares respond much slower.

The concept of learning-by-doing describes the dynamics of decreasing cost with increasing cumulative production. The measure for technological learning is the progress ratio (PR), which is derived from the experience curve. This curve is generally described as follows:

$y=y_{0} * C^{-\pi}$.

In this equation $y$ is the unit cost as a function of the output, $y_{0}$ is the cost of the first unit produced, $C$ is the cumulative production over time and $\pi$ is the learning coefficient. The factor $2^{\pi}$ is called the PR, which is mostly used to indicate the learning capacities of a technology [46].

\section{Appendix B. Key assumptions for the hydrogen scenarios}

The key assumptions for the hydrogen scenarios are given in Tables B1-B6. 
Table B1

Scenario assumptions on hydrogen production efficiency

\begin{tabular}{|c|c|c|c|c|c|c|c|}
\hline & $\begin{array}{l}\text { Coal } \\
\text { gasification (\%) }\end{array}$ & $\begin{array}{l}\text { Oil } \\
\text { (POX) (\%) }\end{array}$ & $\begin{array}{l}\text { Gas } \\
\text { (SMR) (\%) }\end{array}$ & $\begin{array}{l}\text { Biomass } \\
\text { gasification (\%) }\end{array}$ & $\begin{array}{l}\text { Electrolysis } \\
(\%)\end{array}$ & $\begin{array}{l}\text { Solar } \\
\text { thermal }\end{array}$ & $\begin{array}{l}\text { Small-scale } \\
\text { SMR }(\%)\end{array}$ \\
\hline \multicolumn{8}{|l|}{ Pessimistic } \\
\hline \multicolumn{8}{|l|}{ Intermediate } \\
\hline 2005 & 60 & 50 & 75 & 50 & 80 & N/A & 75 \\
\hline 2050 & 62.5 & 70 & 82 & 62.5 & 82 & N/A & 82 \\
\hline \multicolumn{8}{|l|}{ Optimistic } \\
\hline 2005 & 60 & 70 & 75 & 50 & 80 & N/A & 75 \\
\hline 2030 & 62.5 & 72.5 & 82.5 & 62.5 & 82 & N/A & 82 \\
\hline 2100 & 67.5 & 77.5 & 87.5 & 67.5 & 85 & N/A & 85 \\
\hline
\end{tabular}

Table B2

Scenario assumptions for hydrogen production investment cost parameters

\begin{tabular}{|c|c|c|c|c|c|c|c|}
\hline Variable & $\begin{array}{l}\text { Coal } \\
\text { gasification }\end{array}$ & $\begin{array}{l}\text { Oil } \\
\text { (POX) }\end{array}$ & $\begin{array}{l}\text { Gas } \\
\text { (SMR) }\end{array}$ & $\begin{array}{l}\text { Biomass } \\
\text { gasification }\end{array}$ & Electrolysis & $\begin{array}{l}\text { Solar } \\
\text { thermal }\end{array}$ & $\begin{array}{l}\text { Small-scale } \\
\text { SMR }\end{array}$ \\
\hline \multicolumn{8}{|l|}{ Pessimistic } \\
\hline Initial inv. cost & $1150 \$ / \mathrm{kW}$ & $700 \$ / \mathrm{kW}$ & $400 \$ / \mathrm{kW}$ & $1150 \$ / \mathrm{kW}$ & $575 \$ / \mathrm{kW}$ & $2875 \$ / \mathrm{kW}$ & $3000 \$ / \mathrm{kW}$ \\
\hline PR & 0.88 & 0.88 & 0.88 & 0.88 & 0.88 & 0.88 & 0.88 \\
\hline \multicolumn{8}{|l|}{ Intermediate } \\
\hline Initial inv. cost & $1000 \$ / \mathrm{kW}$ & $600 \$ / \mathrm{kW}$ & $350 \$ / \mathrm{kW}$ & $1000 \$ / \mathrm{kW}$ & $500 \$ / \mathrm{kW}$ & $2500 \$ / \mathrm{kW}$ & $3000 \$ / \mathrm{kW}$ \\
\hline \multicolumn{8}{|l|}{ Optimistic } \\
\hline Initial inv. cost & $900 \$ / \mathrm{kW}$ & $550 \$ / \mathrm{kW}$ & $300 \$ / \mathrm{kW}$ & $900 \$ / \mathrm{kW}$ & $450 \$ / \mathrm{kW}$ & $2250 \$ / \mathrm{kW}$ & $2700 \$ / \mathrm{kW}$ \\
\hline PR & 0.785 & 0.785 & 0.785 & 0.785 & 0.785 & 0.785 & 0.785 \\
\hline
\end{tabular}

Table B3

Assumptions on carbon capture and sequestration

\begin{tabular}{lcll}
\hline Technology & Capital cost $(\$ / \mathrm{kW})$ & Efficiency loss $(\%)$ & $\mathrm{CO}_{2}$ capture $(\%)$ \\
\hline Coal (Gasification) & 197 & 3 & 95 \\
Oil (POX) & 185 & 2 & 95 \\
Natural gas (SMR) & 76 & 2 & 88 \\
\hline
\end{tabular}

Table B4

Scenario assumptions for hydrogen transport cost

\begin{tabular}{lcll}
\hline Hydrogen demand (GJ/capita) & Pessimistic (\$/GJ) & Intermediate & Optimistic \\
\hline 0 & 12 & $10 \$ / G J$ & 10 \$/GJ \\
20 & 10 & $6.5 \$ / G J$ & 5 /GJ \\
50 & 8 & 5 \$GJ & 2 \$/GJ \\
70 & 6 & 3 & \\
100 & 6 & 3 & \\
\hline
\end{tabular}


Table B5

Scenario assumptions for local hydrogen distribution cost

\begin{tabular}{|c|c|c|c|c|c|}
\hline$t$ & $\begin{array}{l}\text { Industry } \\
(\$ / G J)\end{array}$ & $\begin{array}{l}\text { Transport } \\
(\$ / G J)\end{array}$ & $\begin{array}{l}\text { Residential } \\
(\$ / G J)\end{array}$ & $\begin{array}{l}\text { Services } \\
(\$ / G J)\end{array}$ & $\begin{array}{l}\text { Other } \\
(\$ / G J)\end{array}$ \\
\hline \multicolumn{6}{|c|}{ Pessimistic } \\
\hline 2005 & 2 & 6 & 3 & 2 & 3 \\
\hline 2100 & 1 & 4 & 2 & 1 & 3 \\
\hline \multicolumn{6}{|c|}{ Intermediate } \\
\hline 2005 & 2 & 5 & 3 & 2 & 3 \\
\hline 2050 & 1 & 3 & 2 & 1 & 3 \\
\hline 2100 & 0.75 & 2 & 1.5 & 0.75 & 3 \\
\hline \multicolumn{6}{|c|}{ Optimistic } \\
\hline 2005 & 1 & 4.5 & 2 & 1 & 3 \\
\hline 2030 & 0.75 & 3 & 1.5 & 0.75 & 3 \\
\hline 2100 & 0.50 & 1 & 1 & 0.50 & 3 \\
\hline
\end{tabular}

Table B6

Scenario assumptions for fuel cell investment cost and transport sector efficiency

\begin{tabular}{|c|c|c|c|c|c|c|}
\hline$t$ & $\begin{array}{l}\text { Industry } \\
(\$ / \mathrm{kW})\end{array}$ & $\begin{array}{l}\text { Residential } \\
(\$ / \mathrm{kW})\end{array}$ & $\begin{array}{l}\text { Service } \\
(\$ / \mathrm{kW})\end{array}$ & $\begin{array}{l}\text { Other } \\
(\$ / k W)\end{array}$ & $\begin{array}{l}\text { Transport } \\
(\$ / \mathrm{kW})\end{array}$ & $\begin{array}{l}\text { FC } \eta \text { transport sector } \\
(\%)\end{array}$ \\
\hline \multicolumn{7}{|c|}{ Pessimistic } \\
\hline 2005 & 1500 & 1400 & 1400 & 1500 & 1200 & 36 \\
\hline 2100 & 800 & 500 & 500 & 800 & 250 & \\
\hline \multicolumn{7}{|c|}{ Intermediate } \\
\hline 2005 & 1500 & 1400 & 1400 & 1500 & 1200 & 36 \\
\hline 2050 & 800 & 500 & 500 & 800 & 250 & 45 \\
\hline 2100 & 500 & 300 & 300 & 500 & 200 & 45 \\
\hline \multicolumn{7}{|c|}{ Optimistic } \\
\hline 2005 & 1350 & 1400 & 1400 & 1500 & 1200 & 40 \\
\hline 2030 & 100 & 100 & 100 & 100 & 100 & 50 \\
\hline 2100 & 50 & 50 & 50 & 100 & 50 & 60 \\
\hline
\end{tabular}

\section{References}

[1] TNO. Waterstof Als Energiedrager, Toekomstige Mogelijkheden in Nederland. Den Haag: TNO; 1975. p. 281.

[2] Caprioglio P. Prospects for a hydrogen economy. Energy Policy 1974;2(3):244-5.

[3] Lucas NJD. Hydrogen and nuclear power. Energy Policy 1976;4(1): 25-36.

[4] Lovins A. Twenty hydrogen myths. Snowmass: Rocky Mountain Institute; 2003 p. 49.

[5] Dunn S. In: Peterson JA, editor. Hydrogen futures: toward a sustainable energy system. Worldwatch Paper. Washington: Worldwatch Institute; 2001. p. 90.

[6] Arnason BA, Sigfuasson TI. Iceland - a future hydrogen economy? Int J Hydrogen Energy 2000;25:389-94.

[7] US Department of Energy. A national vision of America's transition to a hydrogen economy, to 2030 and beyond. Washington, DC: United States Department of Energy; 2002. p. 28.

[8] European Commission. Hydrogen energy and fuel cells, a vision for our future. Brussels: High Level Group for Hydrogen and Fuel Cells; 2003. p. 16.

[9] Shell. Energy needs, choices and possibilities: scenarios to 2050. London: Shell International; 2001. p. 60.

[10] GM. Well-to-wheel analysis of energy use and greenhouse gas emissions of advanced fuel/vehicle systems-a European study. Ottobrun, Germany: L-B systemtechnik; 2002. p. 130.
[11] Ogden JM. Developing an infrastructure for hydrogen vehicles: a Southern California case study. Int J Hydrogen Energy 1999;24:709-30.

[12] Azar C, Lindgren K, Andersson BA. Global energy scenarios meeting stringent $\mathrm{CO}_{2}$ constraints-cost-effective fuel choices in the transportation sector. Energy Policy 2003;31:961-76.

[13] Barreto L, Makihira A, Riahi K. The hydrogen economy in the 21st century: a sustainable development scenario. Int J Hydrogen Energy 2003;28:267-84.

[14] Edmonds J, Clarke J, Dooley J, Kim SH, Smith SJ. Stabilization of $\mathrm{CO}_{2}$ in a B2 world: insights on the roles of carbon capture and disposal, hydrogen, and transportation technologies. Energy Economics 2004;26(4):517-37.

[15] International Energy Agency. World Energy Outlook 2004. Paris: International Energy Agency; 2004. p. 570.

[16] Keith DW, Farrel AE. Rethinking hydrogen cars. Science 2003;301:2.

[17] Morris D. A better way to get from here to there; a commentary on the hydrogen economy and a proposal for an alternative strategy. Minneapolis: Institute for Local Self-Reliance; 2003 p. 27.

[18] Hammerschlag R, Mazza P. Questioning hydrogen. Energy Policy 2005;33(16):2039-43.

[19] Clark II WW, Rifkin J. A green hydrogen economy. Energy Policy 2006;34(17): 2630-9.

[20] van Ruijven BJ. Hydrogen energy, technologies and transition. Utrecht: Utrecht University, Department of Science, Technology and Society; 2003 p. 47.

[21] Ogden JM. Prospects for building a hydrogen energy infrastructure. Ann Rev Energy Environ 1999;24:227-79. 
[22] Turton H, Barreto L. Long-term security of energy supply and climate change. Energy Policy 2006;34(15):2232-50.

[23] Thomas CE, James BD, Lomax FD. Market penetration scenarios for fuel cell vehicles. Int J Hydrogen Energy 1998;23(10):949-66.

[24] Tsuchiya H, Kobayashi O. Mass production cost of pem fuel cell by learning curve. Int J Hydrogen Energy 2004;29(10):985-90.

[25] van den Brink R. Scenario's Voor Duurzame Energie in Verkeer, En Vervoer Beoordeling Op Verschillende Criteria Van Duurzaamheid. Bilthoven: RIVM; 2003 p. 112.

[26] GM. Tank-to-wheel energy utilization for a North American vehicle. General Motors Corporation; 2001. p. 12.

[27] IMAGE-team. The image 2.2 implementation of the Ipcc Sres scenarios. A comprehensive analysis of emissions, climate change and impacts in the 21st century. Bilthoven, The Netherlands: National Institute for Public Health and the Environment; 2001.

[28] van Vuuren DP, van Ruijven BJ, Hoogwijk MM, Isaac M, de Vries HJM. TIMER 2.0, Model description and application. in: Bouwman AF, Hartman MPM, Klein Goldewijk CGM, editors. Integrated modelling of global environmental change. An overview of IMAGE 2.4. Bilthoven, The Netherlands: Netherlands Environmental Assessment Agency; 2006.

[29] de Vries HJM, van Vuuren DP, den Elzen MGJ, Janssen MA. The timer image energy regional (Timer) model. Bilthoven: National Institute for Public Health and the Environment (RIVM); 2001. p. 188.

[30] Hoogwijk M. On the global and regional potential of renewable energy sources. PhD thesis, Science Technology and Society, Utrecht University, Utrecht; 2004. p. 256.

[31] Hendriks C, Graus W, van Bergen F. Global carbon dioxide storage potential and costs. Ecofys: Utrecht; 2004. p. 64.

[32] van Ruijven BJ. Hydrogen in the future global energy system. MSc thesis, Environmental Science, Utrecht University, Utrecht; 2003. p. 102.

[33] Argote L, Epple D. Learning curves in manufacturing. Science 1990;247:920-4.

[34] Rogner HH. Hydrogen technologies and the technology learning curve. Int J Hydrogen Energy 1998;23(9):833-40.

[35] Hendriks C, Harmelink M, Hofmans Y, de Jager D. Climate neutral energy carriers in the regulatory energy tax. Utrecht: Ecofys; 2002 p. 60.

[36] Damen K, Troost Mv, Faaij A, Turkenburg W. A comparison of electricity and hydrogen production systems with $\mathrm{CO}_{2}$ capture and storage. Part $\mathrm{A}$ : review and selection of promising conversion and capture technologies. Progress in Energy and Combustion Science 2006;32(2):215-46.

[37] Wurster R, Zittel DW. Hydrogen energy. Ottobrun, Germany: L-B systemtechnik; 1994.

[38] Reijnders HTJ, de Groot A, Lako P. Evaluatie Van Waterstof-Gebaseerde Concepten En Systemen. Petten: ECN; 2001 p. 41.
[39] Tillemans FWA, de Groot A. Evaluation of benefits and barriers of hydrogen in residential districts. Petten: ECN; 2002 p. 91.

[40] Mintz M, Folga S, Molburg J, Gillete J. Cost of some hydrogen fuel infrastructure options. Chicago: Argone National Laboratory; 2002.

[41] van Vuuren DP, Den Elzen MGJ, Lucas PL, Eickhout B, Strengers BJ, van Ruijven BJ, et al. Stabilizing greenhouse gas concentrations at low levels: an assessment of reduction strategies and costs. Climatic Change, accepted for publication.

[42] den Elzen MGJ, Lucas P. Fair 2.0-a decision-support tool to assess the environmental and economic consequences of future climate regimes. Bilthoven, The Netherlands: National Institute of Public Health and the Environment; 2003 p. 91.

[43] den Elzen MGJ, Meinshausen M. Meeting the $\mathrm{Eu} 2{ }^{\circ} \mathrm{C}$ climate target: global and regional emission implications. Bilthoven: Netherlands Environmental Assessment Agency (MNP); 2005 p. 45.

[44] van Vuuren DP, de Vries HJM. Mitigation scenarios in a world oriented at sustainable development: the role of technology, Efficiency and Timing. Climate Policy 2001;1:189-210.

[45] Azar C, Lindgren K, Andersson BA. Hydrogen or methanol in the transportation sector. Goteborg: Department of Physical Resource Theory, Chalmers University of Technology; 2000 p. 69.

[46] Harmon C. Experience curves of photovoltaic technology. Laxenburg: IIASA; 2000 p. 17.

[47] Padro CEG, Putsche V. Survey of the economics of hydrogen technologies. Golden, CO: National Renewable Energy Laboratory; 1999 p. 54.

[48] IEA/AFIS. In: Elam N, editor. Automotive fuels survey, raw materials and conversion, vol. 1. Innas BV: Breda; 1996. p. 172.

[49] Momirlan M, Veziroglu TN. Current status of hydrogen energy. Renewable Sustainable Energy Rev 2002;6:141-79.

[50] National Research Council. The hydrogen economy: opportunities, costs, barriers, and R\&D needs. Washington, DC: The National Academies Press; 2004. p. 240.

[51] Hamelinck CN, Faay APC. Future prospects for production of methanol and hydrogen from biomass. Utrecht: Utrecht University; 2001 p. 94.

[52] Glatzmaier G, Blake D, Showalter S. Assessment of methods for hydrogen production using concentrated solar energy. Golden, CO, USA: NREL; 1998 p. 21.

[53] Bolton JR. Solar photoproduction of hydrogen: a review. Solar Energy 1996;57(1):37-50.

[54] IEA/AFIS. In: Walwijk Mv, Buckman M, Troelstra WP, Achten PAJ, editors. Automotive fuels survey, distribution and use, vol. 2. Innas BV: Breda; 1996. p. 350.

[55] Dutton G. Hydrogen energy technology. Norwich: Tyndall Centre for Climate Change Research; 2002 p. 31. 